\title{
Evaluation of A-azepano-triterpenoids and related derivatives as antimicrobial and antiviral agents
}

\author{
Oxana Kazakova ${ }^{1} \cdot$ Elena Tret'yakova ${ }^{1} \cdot$ Dmitry Baev $^{2}$
}

Received: 8 April 2021 / Revised: 17 June 2021 / Accepted: 24 June 2021 / Published online: 12 July 2021

(c) The Author(s), under exclusive licence to the Japan Antibiotics Research Association 2021

\begin{abstract}
A series of semisynthetic triterpenoids with A-ring azepano- and A-seco-fragments as well as hydrazido/hydrazonosubstituents at $\mathrm{C} 3$ and $\mathrm{C} 28$ has been synthesized and evaluated for antimicrobial activity against key ESKAPE pathogens and DNA viruses (HSV-1, HCMV, HPV-11). It was found that azepanouvaol 8, 3-amino-3,4-seco-4(23)-en derivatives of uvaol $\mathbf{2 1}$ and glycyrrhetol-dien $\mathbf{2 2}$ as well as azepano-glycyrrhetol-tosylate $\mathbf{3 2}$ showed strong antimicrobial activities against MRSA with MIC $\leq 0.15 \mu \mathrm{M}$ that exceeds the effect of antibiotic vancomycin. Azepanobetulinic acid cyclohexyl amide 4 exhibited significant bacteriostatic effect against MRSA $(\mathrm{MIC} \leq 0.15 \mu \mathrm{M})$ with low cytotoxicity to HEK-293 even at a maximum tested concentration of $>20 \mu \mathrm{M}$ (selectivity index SI 133) and may be considered a noncytotoxic anti-MRSA agent. Azepanobetulin 1, azepanouvaol 8, and azepano-glycyrrhetol $\mathbf{1 5}$ showed high potency towards $\mathrm{HCMV}\left(\mathrm{EC}_{50} 0.15\right.$; $0.11 ; 0.11 \mu \mathrm{M})$ with selectivity indexes $\mathrm{SI}_{50} 115 ; 136 ; 172$, respectively. The docking studies suggest the possible interactions of the leading compounds with the molecular targets.
\end{abstract}

\section{Introduction}

Microbial infections, such as bacteria, fungi, and viruses, are a cause of morbidity and mortality worldwide [1]. Increased resistance to bacterial and viral infections requires the search for new antibiotic and antiviral drugs [2]. Natural products have historically been a prolific and unsurpassed source for new lead antibacterial compounds and therefore novel scaffolds are constantly of interest. Many secondary metabolites from plants consisting of terpenes and polyphenols can combat the problem of resistant bacteria and viruses as well as drug residue hazards [3]. A wide variety of these compounds have shown to exhibit activity against

Supplementary information The online version contains supplementary material available at https://doi.org/10.1038/s41429021-00448-9.

Oxana Kazakova

obf@anrb.ru

1 Ufa Institute of Chemistry of the Ufa Federal Research Centre of the Russian Academy of Sciences, 71 Prospect Oktyabrya, 450054 Ufa, Russian Federation

2 N.N. Vorozhtzov Novosibirsk Institute of Organic Chemistry SB RAS, 9, Lavrent'ev Ave., Novosibirsk 630090, Russian Federation various bacterial and viral pathogens, yeasts, or molds $[4,5]$ and also served as prototypes, which have been modified through chemical synthesis to afford therapeutic agents with improved potency, stability, or superior drug-like properties [6, 7].

Pentacyclic triterpenoids are widespread in the plant kingdom and display important biological properties, such as anticancer, antiviral, antibacterial, and antimalarial activities, among others [8-13]. Thus, $\alpha$-amyrin, betulinic acid, and betulin aldehyde exhibit the antimicrobial activity against clinical isolates of methicillin-resistant (MRSA) and methicillin-susceptible $S$. aureus with MICs ranging from 64 to $512 \mu \mathrm{g} \mathrm{ml}^{-1}$, and in combination with vancomycin and methicillin the reduced MIC with a range from 0.05 to $50 \%$ was observed [14]. Oleanolic acid has been shown to exhibit appreciable anti-staphylococcal activity against $S$. aureus and MRSA, with MICs in the range of 8 and $16 \mu \mathrm{g} \mathrm{ml}^{-1}$ [15], whereas ursolic acid showed a good antimicrobial activity against gram $(+)$ pathogens including a MRSA strain, with a MIC value of $64 \mu \mathrm{g} \mathrm{ml}^{-1}$ and a synergistic effect with ampicillin and tetracycline against this strain [16]. As early as 1994, betulinic acid was shown to inhibit the infectivity of HIV-1 in vitro with $\mathrm{EC}_{50}$ value of $1.4 \mu \mathrm{M}$ [17] and its systematic structural modifications resulted in the identification of bevirimat, BMS-955176 and GSK-2838232 entered clinical trials [18]. Up to date, 
various other triterpenoid lead compounds targeting $\mathrm{HCV} / \mathrm{EBOV}, \mathrm{SARS}-\mathrm{CoV}$, and influenza viruses have been explored [19-21].

In order to further study the antimicrobial and antiviral potency of triterpenic derivatives, a series of semisynthetic derivatives with A-ring azepano- as well as hydrazido/ hydrazono-substituents at C3 and C28 were evaluated against a key ESKAPE pathogens (including MRSA strain) and DNA viruses (human herpes simplex virus 1 (HSV-1), cytomegalovirus, and papillomavirus 11). For this purpose, we used the possibilities of the Community for Open Antimicrobial Drug Discovery program (http://www.co-a dd.org) for antibacterial and antifungal activities screening and Division of Microbiology and Infectious Diseases of the National Institutes of Allergy and Infectious Diseases (http://www.niaid-aacf.org/) program for antiviral assays. Cytotoxicity of the representative compounds against the noncancerous human embryonic kidney cells was studied as well as docking studies of the leading compounds possible interactions with the molecular targets was performed.

\section{Results and discussion}

\section{Chemistry}

Recently we have showed that triterpenoids with A-ring azepano- and hydrazido-, hydrazono-substituents are an important group of derivatives with antibacterial activities [22-25]. To compare the influence of substituents in different positions of the triterpene core on antibacterial, fungicidal, and antiviral activities, a series of previously synthesized compounds 1-22 (Fig. 1) and new derivatives 24, 26, 29-34, 36, 37 (Scheme 1) were taken into biological screening.

The synthesis of new derivatives is shown at Scheme 1. $N$-Acylation of lupane, ursane and oleanane-type triterpenic acids 23, 25 and 27, 28 by imidazole, 3- or 4pyridinoylhydrazides by chloride method led to C28amides 24, 26, 29-31 with yields of 72-78\% after purification by column chromatography. The introduction of the toluenesulfonyl group to azepano-glycyrrhetol was carried out by the reaction of $\mathbf{1 5}$ with $p$-TsOH to give compound 32 in $88 \%$ yield. Azepanobetulin 1 was oxidized to azepanobetulinic aldehyde 33 by $\mathrm{PCC}$ in $\mathrm{CH}_{2} \mathrm{Cl}_{2}$ and following reaction with 4-pyridinoylhydrazide in $\mathrm{MeOH}$ afforded hydrazido-hydrazone 34. Under the same conditions betulonic aldehyde $\mathbf{3 5}$ was reacted with 3-pyridinoylhydrazide to form a mixture of C28-mono- 36 (65\%) and C3,C28-bis-substituted 37 (7\%) derivatives after isolation by column chromatography.

The structures and the purity of the synthesized compounds 24, 26, 29-34, 36, and 37 were confirmed by NMR spectroscopy. In the ${ }^{13} \mathrm{C}$ NMR spectra of compounds 24, 26, 29-31 the carbon atom signals of the -CONH- and -NHCO- groups were detected at $\delta 174.0-174.73$ and $\delta$ 161.62-161.90 ppm, respectively, in the ${ }^{1} \mathrm{H}$ NMR spectra $\mathrm{NH}$ proton signals resonated at $\delta 9.21-10.71 \mathrm{ppm}$. The ${ }^{1} \mathrm{H}$ NMR spectra of amide $\mathbf{2 4}$ contained the signals of the imidazole ring protons at $\delta 7.02-7.52 \mathrm{ppm}$ as well as in the ${ }^{1} \mathrm{H}$ NMR spectra of hydrazides 26, 29-31 the signals of the aromatic ring protons were observed at $\delta 7.38-8.64$ ppm. In the ${ }^{13} \mathrm{C}$ NMR spectra of tosylate 32 the signals of the aromatic carbon atoms were observed at $\delta$ 123.08-144.64 ppm, and the signals of the aromatic protons in the ${ }^{1} \mathrm{H}$ NMR spectra were appeared at $\delta 7.35$ and 7.75 ppm as multiplets. The characteristic signal of aldehyde group proton at $\delta 9.80 \mathrm{ppm}$ and signal of the carbon atom at $\delta 202.0 \mathrm{ppm}$ were observed in the NMR spectra of compound 33. The ${ }^{13} \mathrm{C}$ NMR spectra of compounds $34,36,37$ contain $-\mathrm{C}=\mathrm{N}-\mathrm{NH}-$ group carbon signal at $\delta$ 161.96-166.0 ppm, the NH proton in the ${ }^{1} \mathrm{H}$ NMR spectra appeared as a broadened signal at $\delta 10.05-10.99 \mathrm{ppm}$.

Thus, a series of new A-azepanotriterpenoids as well as C28amides, C3, C28-dihydrazides, and isonicotinoylhydrazones has been synthesized for biological screening.

\section{Biological activity}

\section{Evaluation of antimicrobial activity}

Despite the discovery of antibiotics that have saved millions of lives from microbial infections, the latter continue to pose a serious threat to public health due to the emergence of resistant strains. MRSA Staphylococcus aureus is one of the most prevalent triggers of community-associated multi drug resistance bacterial infection and resistance to methicillin is now widely described in the community setting, thus the development of new drugs or alternative therapies is urgently necessary $[26,27]$.

Plant-derived triterpenoids represent a promising class of molecules with a multitude of activities, including antimicrobial, that make them of reference for drug-discovery as proven by the numerous reports and even clinical trials [5, 28, 29]. Recently, we have shown that 3-amino-3,4seco-28-amino-lup-4(23),20(29)-dien exhibited significant bacteriostatic effect against MRSA $\left(\mathrm{MIC} \leq 0.25 \mu \mathrm{g} \mathrm{ml}^{-1}\right.$ ) that exceeds the effect of vancomycin [23]. Oleanonic acid amide with diethylentriamine was efficient against $E$. coli and $P$. aeruginosa with MICs of 25 and $50 \mu \mathrm{M}$ [30]. Azepanobetulin and its amide derivative showed in vitro antibacterial activity on the H37Rv MTB strain in aerobic and anaerobic conditions and antibacterial potency against nontuberculous mycobacterial strains ( $M$. avium, M. abscessus) [31], and also triterpene conjugates with 
Fig. 1 Azepano-, hydrazido/ hydrazono-, and seco-triterpenic derivatives: azepanobetulin $\mathbf{1}$, tosylate $\mathbf{2}$, acetohydrazide $\mathbf{3}$, amides 4-7, 9, azepanouvaol 8 , azepanoallobetulin 10, abeolupanes $\mathbf{1 1}$ and $\mathbf{1 2}$, azepanomessagenin $\mathbf{1 3}$, azepanoerythrodiol 14, azepanoglycyrrhetinic $\mathbf{1 5}$ and $\mathbf{1 6}$, hydrazones 17, 19, 20, hydrazide 18, 3-amino-3,4-seco4(23)-en triterpenic derivatives of uvaol 21, and glycyrrhetoldien 22

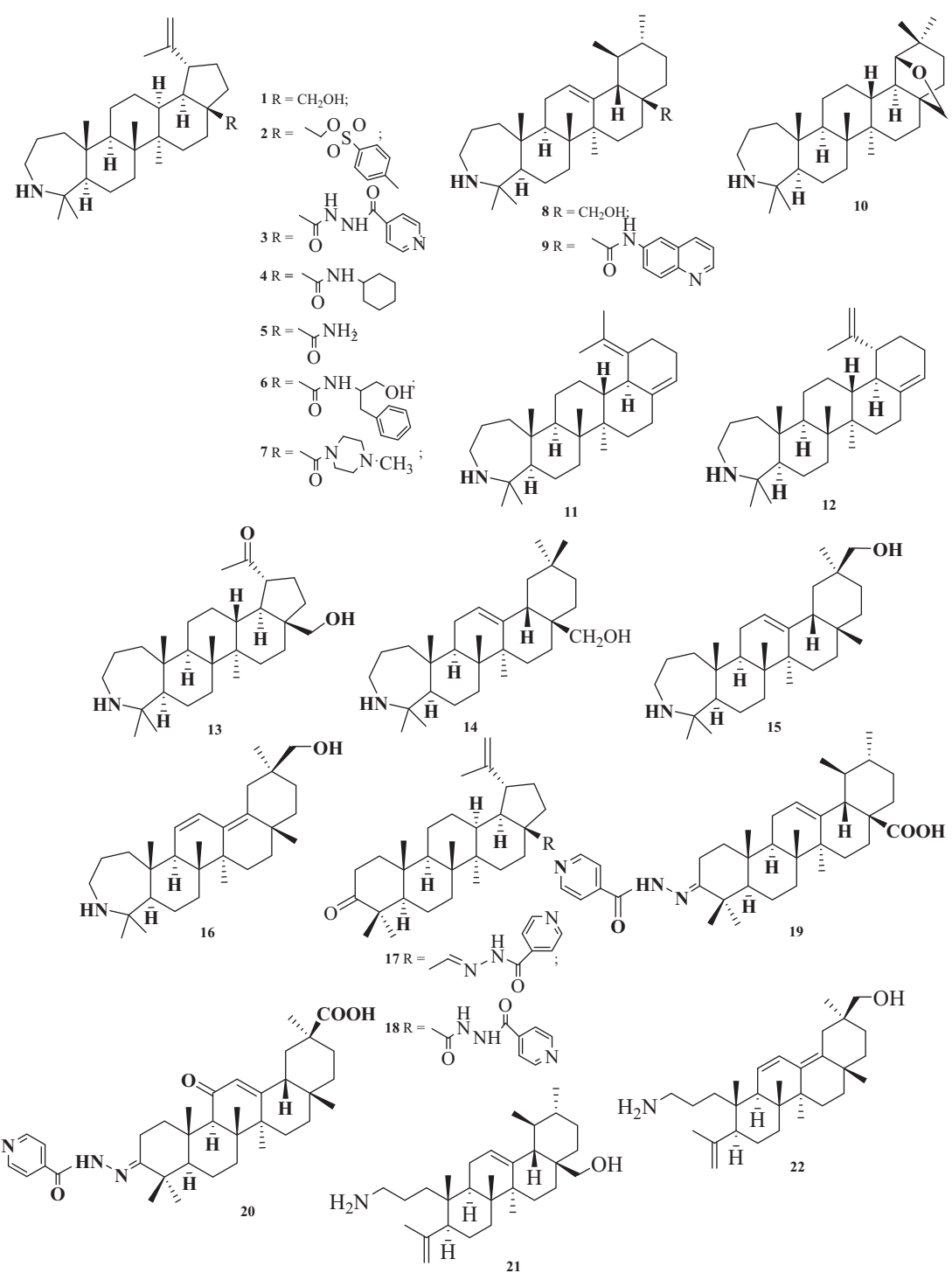

hydrazine hydrate and isoniazide demonstrated from high minimum inhibitory concentration (MIC $\leq 10 \mu \mathrm{g} \mathrm{ml}^{-1}$ ) to excellent (MICs from 0.19 to $1.25 \mu \mathrm{g} \mathrm{ml}^{-1}$ ) activity against MTB H37RV and some SDR-strains [24].

Due to our interest in the discovery and development of anti-infective compounds, semisynthetic triterpenoids 1-4, 8-22, 26, 29-32, 34, 36, 37 were screened for antibacterial activity against a panel of gram-positive and gram-negative bacterial isolates, and for antifungal activity against two fungi at concentration $20 \mu \mathrm{M}$. The percentage of growth inhibition was calculated for each well, using the negative control (media only) and positive control (bacteria without inhibitors) on the same plate as references.

The initial screening results of in vitro antimicrobial activity are presented in Table 1. Samples with inhibition values equal to or above $80 \%$ were classified as active. Compounds 17-20, 26, 29-31, 36, 37 did not exhibit antibacterial activity against the gram-positive
(Staphylococcus aureus MRSA), or gram-negative (Escherichia coli, Klebsiella pneumoniae, Acinetobacter baumannii, and Pseudomonas aeruginosa) bacteria tested and were also inactive against fungi (Candida albicans and Cryptococcus neoformans) at $20 \mu \mathrm{M}$.

On the other hand, compounds 1, 2, 4, 8-16, 21, 22, 32, 34 showed the highest growth inhibition against $S$. aureus bacteria culture with ranged from $84.80 \%$ to $99.76 \%$ as well as compounds 2, 4, 9-12, 14-16, 22, 32, 34 had excellent fungicidal activity against culture of fungi's $C$. albicans and C. neoformans var. grubii. Compounds $\mathbf{1}, \mathbf{3}, \mathbf{8}$, and $\mathbf{2 1}$ were also active against fungi $C$. neoformans (Table 1).

Triterpenic alcohols $\mathbf{1}, \mathbf{8}$ and 3,4-seco-uvaol 21 were active against bacteria $S$. aureus and fungi $C$. neoformans, whereas, azepanoallobetulin 10, abeo-lupanes 11, 12, azepanoerythrodiol 14, azepano-glycyrrhetinic $\mathbf{1 5}, \mathbf{1 6}$, and 3,4-seco-derivatives of glycyrrhetol-dien 22 inhibited the S. aureus and both studied fungi's. Azepanomessagenin $\mathbf{1 3}$ 


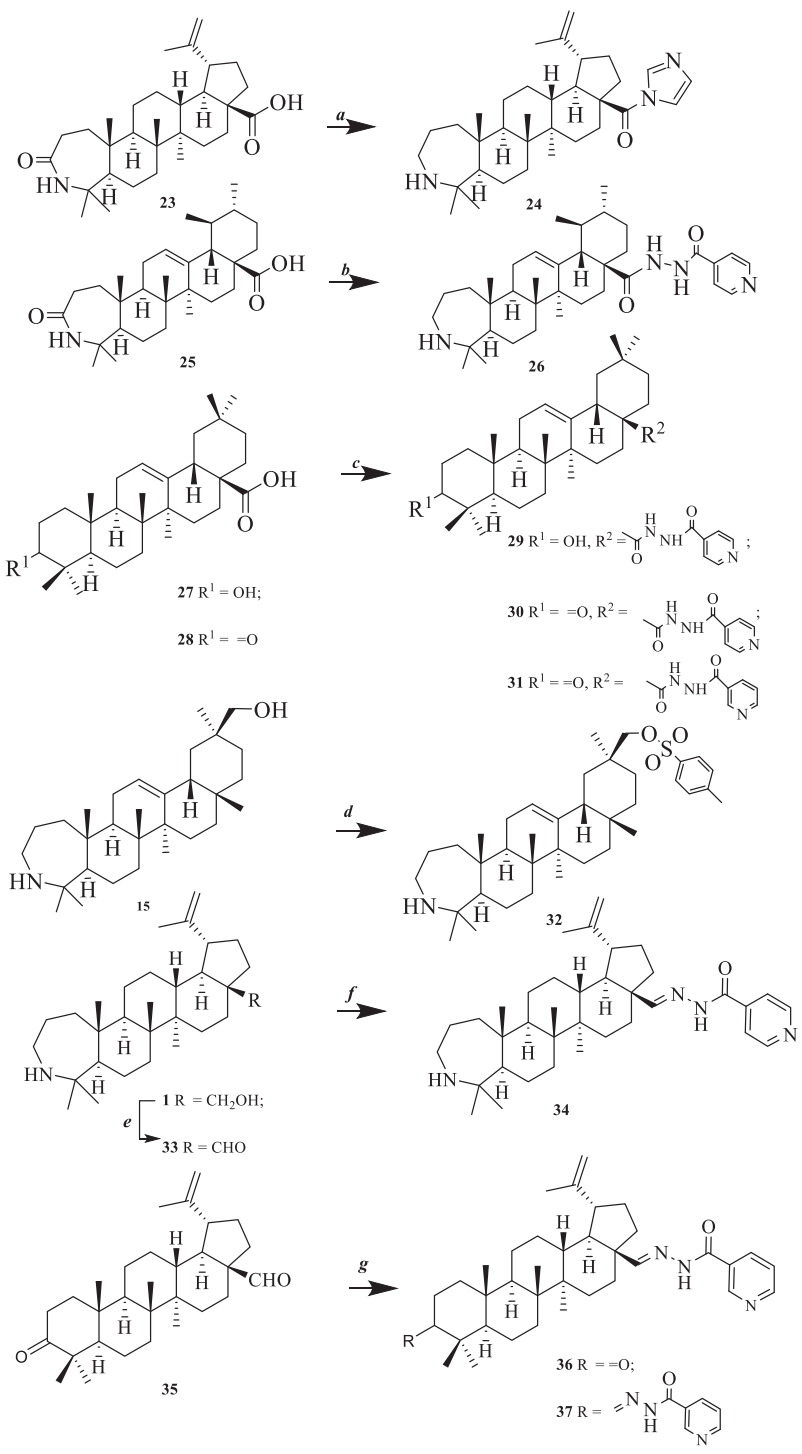

Scheme 1 Synthesis of compounds 24, 26, 29-34, 36, 37. Reagents and conditions: a (1) $(\mathrm{COCl})_{2}, \mathrm{CH}_{2} \mathrm{Cl}_{2}, 22^{\circ} \mathrm{C}, 3 \mathrm{~h}$; (2) imidazole, DMAP, $\mathrm{CH}_{2} \mathrm{Cl}_{2}$, reflux, $3 \mathrm{~h}$; (3) $\mathrm{LiAlH}_{4}$, THF, reflux, $1 \mathrm{~h}$; b (1) $(\mathrm{COCl})_{2}, \mathrm{CH}_{2} \mathrm{Cl}_{2}, 22^{\circ} \mathrm{C}, 3 \mathrm{~h}$; (2) 4-pyridinoylhidrazide, $\mathrm{CH}_{2} \mathrm{Cl}_{2}$, reflux, $3 \mathrm{~h}$; (3) $\mathrm{LiAlH}_{4}$, THF, reflux, $1 \mathrm{~h}$; c (1) $(\mathrm{COCl})_{2}, \mathrm{CH}_{2} \mathrm{Cl}_{2}, 22^{\circ} \mathrm{C}$, $3 \mathrm{~h}$; (2) 4-pyridinoylhidrazide for compounds $29, \quad 30$ and 3-pyridinoylhidrazide for compound $\mathbf{3 1}, \mathrm{CH}_{2} \mathrm{Cl}_{2}$, reflux, $3 \mathrm{~h}$; d $p$ - $\mathrm{TsCl}$, pyridine, DMAP, $48 \mathrm{~h}, 22^{\circ} \mathrm{C}$; e PCC, $\mathrm{CH}_{2} \mathrm{Cl}_{2}, \mathrm{rt}, 30 \mathrm{~min}$; f 4pyridinoylhidrazide, $\mathrm{MeOH}, 22^{\circ} \mathrm{C}, 8 \mathrm{~h} . \mathrm{g}$ 3-pyridinoylhidrazide, $\mathrm{MeOH}, 22^{\circ} \mathrm{C}, 6 \mathrm{~h}$

was active only against gram-positive MRSA. The introduction of the toluenesulfonyl fragment (compound 2) leads to the appearance of activity against $C$. albicans as compared with the initial compound $\mathbf{1}$, tosylate $\mathbf{3 2}$ also has activity against two fungi's and MRSA. A similar activity is observed for amides $\mathbf{4}$ and $\mathbf{9}$. The introduction of a pyridinoylhydrazide residues into the $\mathrm{C} 3$ and/or $\mathrm{C} 28$ positions of triterpene derivatives leads either to a complete loss of antimicrobial activity (hydrazones 17, 19, 20, 36, 37 and hydrazides 18, 26, 29-31), or to a partial loss of activity against MRSA (acetohydrazide 3), and only in the case of hydrazone 34, an increase of activity was observed in comparison with the initial alcohol $\mathbf{1}$.

Among the samples tested, eighteen showed antimicrobial activity and have been selected for hitconfirmation. For these compounds, a minimum inhibitory concentration and cytotoxicity against a human embryonic kidney cell line $(\mu \mathrm{M})$ were determined for the above cultures of bacteria and fungi. Colistin and vancomycin were used as positive antibacterial controls for gram-negative and gram-positive bacteria, respectively. Fluconazole was used as a positive antifungal control for $C$. albicans and $C$. neoformans. Tamoxifen was used as a positive cytotoxicity standard (Table 2).

Notably, compounds $1,3,11,13$, and 34 do not show antibacterial activity after the repeated screening. Compounds 2, 9, 10, 12, and 14-16 showed weak activity against MRSA $S$. aureus (MIC ranges from 1.25 to $10 \mu \mathrm{M}$ ), while the compounds $4,8,21,22$, and 32 exhibited significant bacteriostatic effect against MRSA (MIC $\leq 0.15$ $\mu \mathrm{M})$ that exceeds the effect of the clinically used antibiotic vancomycin $(\mathrm{MIC}=0.625 \mu \mathrm{M})$. Compounds $2, \mathbf{1 0}, \mathbf{1 2}$, and 22 were also active against fungi $C$. albicans (MIC $\leq 0.15$ $\mu \mathrm{M}$ for compounds 2 and $\mathbf{1 2}$; MIC $=1.25 \mu \mathrm{M}$ for compound 22, and $\mathrm{MIC}=10 \mu \mathrm{M}$ for compound $\mathbf{1 0}$ ) whereas compounds 15, 21, and 22 inhibited the growth of fungi C. neoformans (MIC ranges from 10 to $20 \mu \mathrm{M}$ ) (Table 2).

To study the drug-like properties of the active compounds, all eighteen compounds were evaluated for cytotoxic properties for $50 \%$ cytotoxic concentration $\left(\mathrm{CC}_{50}\right)$ values against healthy human (HEK-293) cells and selectivity $\left(\mathrm{SI}=\mathrm{CC}_{50} / \mathrm{MIC}\right)$ (Table 2$)$. The values of cytotoxicity of triterpene derivatives $2,8-10,12,14,15,21,22$, and 32 were comparable with the values of the minimum inhibitory concentrations for bacteria $S$. aureus and fungi $C$. albicans and $C$. neoformans, suggesting that these compounds do not have clear selectivity between microbial and human cells. Azepanobetulinic acid amide $\mathbf{4}$ and azepano-glycyrrhetol 16 did not show any noticeable cytotoxicity against HEK-293 cell lines and the selectivity index values for these compounds were 133 and 2 , respectively. This finding is very significant to design azepanotriterpenoids as noncytotoxic antibacterial agents.

\section{Evaluation of antiviral activity}

Viral infections cause many serious human diseases with high mortality rates. Given the high mutation rate of viruses and their serious threat to public health, there is a high urgency to develop new antiviral drugs to combat these pathogens. Triterpenoids have also been crucial for antiviral drug discovery [32] and mainly involve effects on DNA viruses [33-35]. For example, Bevirimat [3-O-(3',3'-dimethylsuccinyl)-betulinic 
Table 1 Percentage antibacterial and antifungal growth inhibition of compounds 1-4, 8-22, 26, 29-32, 34, 36, and 37 at concentration $20 \mu \mathrm{M}^{\mathrm{a}}$

\begin{tabular}{|c|c|c|c|c|c|c|c|}
\hline \multirow[t]{2}{*}{ Compound } & \multirow{2}{*}{$\begin{array}{l}\text { Gram-positive bacteria } \\
\text { S. aureus }\end{array}$} & \multicolumn{4}{|c|}{ Gram-negative bacteria } & \multicolumn{2}{|l|}{ Fungi } \\
\hline & & E. coli & K. pneumoniae & P. aeruginosa & A. baumannii & C. albicans & C. neoformans \\
\hline 1 & 99.76 & -0.25 & 7.50 & 23.35 & 20.01 & 8.38 & 98.72 \\
\hline 2 & 92.85 & 9.61 & 3.96 & -0.92 & 17.53 & 101.70 & 101.50 \\
\hline 3 & 47.83 & -4.72 & 4.78 & -3.74 & 28.31 & 11.74 & 95.40 \\
\hline 4 & 94.50 & 16.13 & 13.10 & -4.37 & 23.25 & 101.00 & 95.14 \\
\hline 8 & 97.80 & 15.15 & -1.29 & 23.40 & 32.17 & 18.07 & 98.21 \\
\hline 9 & 84.80 & -6.12 & 19.57 & -8.27 & 45.49 & 100.40 & 96.16 \\
\hline 10 & 94.72 & -1.37 & -15.47 & 5.25 & 12.84 & 100.10 & 96.93 \\
\hline 11 & 87.80 & 0.85 & 1.07 & 5.04 & 16.18 & 100.70 & 91.82 \\
\hline 12 & 97.63 & 1.92 & -8.12 & -0.30 & 16.58 & 101.60 & 101.80 \\
\hline 13 & 98.34 & 2.59 & 6.61 & 18.49 & 7.65 & 12.53 & -6.14 \\
\hline 14 & 98.25 & 21.81 & 18.85 & 13.01 & 33.54 & 101.50 & 112.50 \\
\hline 15 & 98.96 & 7.17 & 14.41 & 25.39 & 34.72 & 100.40 & 100.30 \\
\hline 16 & 99.07 & 1.64 & 1.86 & 14.57 & 41.07 & 99.54 & 100.30 \\
\hline 17 & 9.62 & -3.99 & 5.25 & -6.21 & 19.13 & 17.50 & -12.79 \\
\hline 18 & 18.34 & -1.26 & 2.91 & 3.81 & 39.78 & 62.06 & 1.53 \\
\hline 19 & 9.06 & -0.71 & 12.60 & 8.48 & 34.89 & 4.77 & -3.32 \\
\hline 20 & 0.19 & -3.33 & -0.30 & 3.96 & 37.10 & 7.47 & -2.81 \\
\hline 21 & 91.97 & 19.03 & 6.36 & 10.65 & 29.64 & 21.82 & 95.14 \\
\hline 22 & 90.28 & 23.74 & 24.29 & 9.90 & 36.00 & 99.58 & 101.90 \\
\hline 26 & 6.66 & 1.45 & 12.58 & 6.19 & 15.42 & 7.32 & -1.15 \\
\hline 29 & -4.12 & -4.64 & -4.92 & 3.81 & 0.87 & 7.53 & -11.51 \\
\hline 30 & 14.72 & 0.30 & 3.19 & 1.55 & 10.69 & 10.53 & -8.72 \\
\hline 31 & -5.16 & -1.34 & -9.72 & 7.12 & -6.61 & 15.45 & 17.65 \\
\hline 32 & 97.00 & 2.89 & 9.14 & 0.87 & 13.08 & 100.30 & 102.40 \\
\hline 34 & 97.34 & 0.01 & -12.00 & 12.77 & 21.96 & 100.6 & 105.1 \\
\hline 36 & 14.78 & 3.08 & 10.74 & 16.58 & 13.81 & 8.44 & 1.52 \\
\hline 37 & -10.09 & -3.06 & -6.88 & 8.30 & 7.18 & 9.58 & 17.65 \\
\hline
\end{tabular}

${ }^{a}$ Highest percentile of antibacterial/antifungal growth inhibition is highlighted in bold

acid] has been shown to inhibit HIV-1 maturation by a previously undescribed mechanism [33]. Betulin alone and in combination with acyclovir has been reported to inhibit Herpes simplex virus types I and II [36]. Betulinic and betulonic acids are also active against HSV, as well as against influenza A and ECHO-6 picornavirus [37, 38]. The synergistic effect of rimantadine and betulin-derived compounds combinations against reproduction influenza virus type $\mathrm{A}$ (H1N1, H7N1, and H3N2) and B in vivo is established [39]. Recent data provide evidence for the sensitivity of RNA viruses, for example, the significant synergistic effects of betulin derivatives, when combined with $3^{\prime}$-amino-3'-deoxyadenosine against Semliki Forest virus was shown [40].

Human cytomegalovirus (HCMV) is an opportunistic viral pathogen of the Herpesviridae family which infects newborns and immunosuppressed individuals with high virulence, leading to severe morbidity and mortality. It was shown that betulin/betulinic acid and artesunic acid hybrids [41] and triazine derivatives of allobetulin and betulinic acid [42] were active against $\mathrm{HCMV}$ with $\mathrm{EC}_{50}$ in the micromolar range.

Papillomaviruses are small, non-enveloped DNA viruses that infect and replicate in the cutaneous or mucosal epithelia of human and other mammals [43]. There are over 80 types of human papillomavirus (HPV), which cause conditions ranging from plantar (HPV-1) and genital warts (HPV-6 and -11) to cervical cancer (HPV-16, - 18, and -31). HPV-6 and -11 are also responsible for laryngeal papillomatosis, a rare but very serious infection of the respiratory tract. Antiviral agents capable of specifically inhibiting PV replication could play an important role in the treatment of these diseases, but unfortunately, no such efficient antiviral agent exists at present. A series of triterpenoids were found to inhibit HPV-11 and HPV-16 in the micromolar range [44-46].

We submitted compounds 1, 2, 5-8, 10, 12, 14-16, and 24 to the Division of Microbiology and Infectious Diseases 


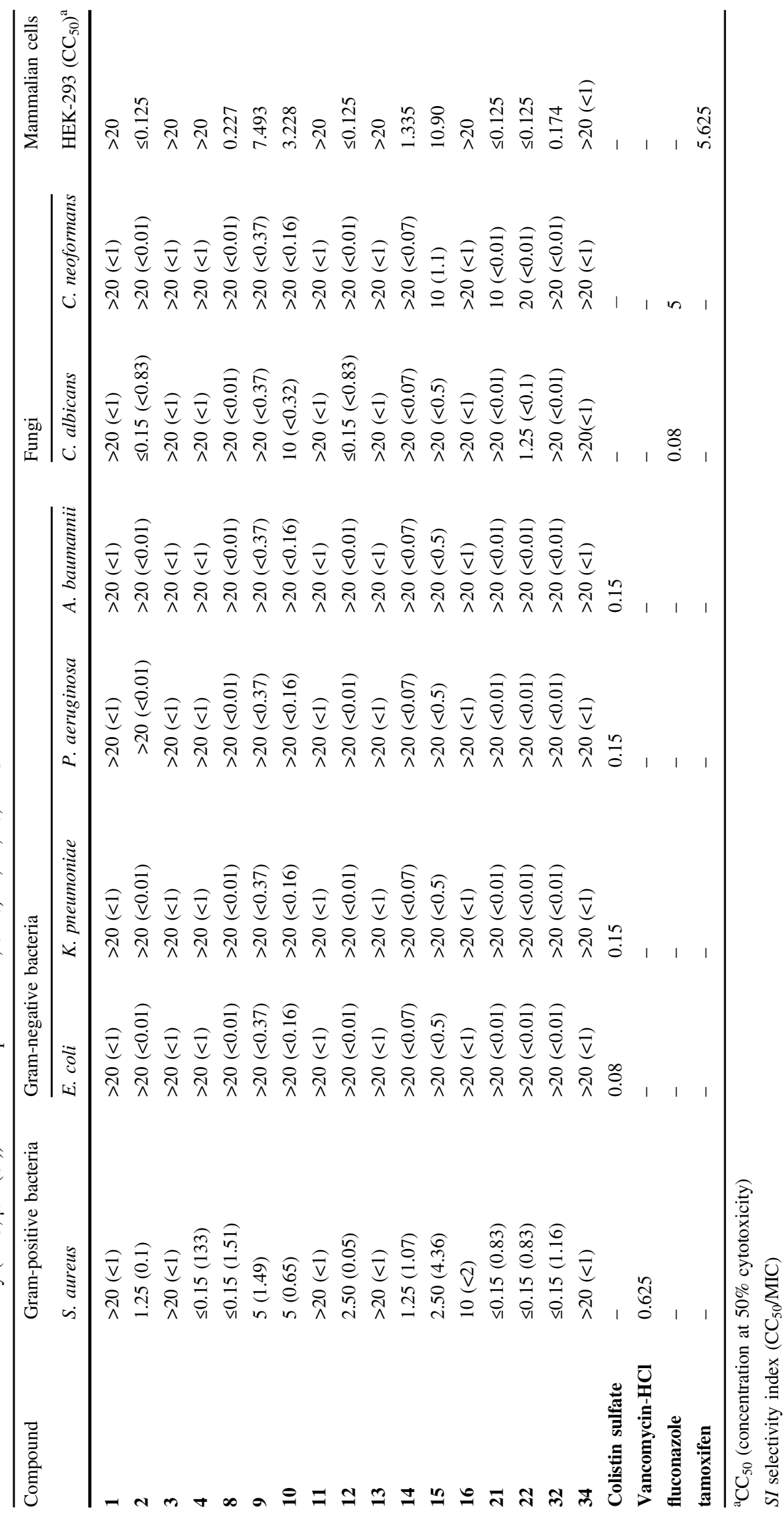


Table 3 In vitro antiviral activity of compounds $1,2,5-8,10,12,14-16$, and 24

\begin{tabular}{|c|c|c|c|c|c|}
\hline Compound (ARB no.) & $\mathrm{EC}_{50}$ & $\mathrm{EC}_{90}$ & $\mathrm{CC}_{50}$ & $\mathrm{SI}_{50}$ & $\mathrm{SI}_{90}$ \\
\hline \multicolumn{6}{|l|}{ Herpes simplex virus $1^{\mathrm{a}}$} \\
\hline $1(17-000257)$ & $>6$ & $>6$ & 25.67 & $<4$ & $<4$ \\
\hline $6(17-000261)$ & $>1.20$ & $>1.20$ & 3.22 & $<3$ & $<3$ \\
\hline $8(17-000259)$ & $>6$ & $>6$ & 7.87 & $<1$ & $<1$ \\
\hline $14(17-000258)$ & $>1.20$ & $>1.20$ & 2.78 & $<2$ & $<2$ \\
\hline $15(17-000260)$ & $>6$ & $>6$ & 10.63 & $<2$ & $<2$ \\
\hline Acyclovir & 0.83 & $>150$ & $>150$ & $>181$ & 1 \\
\hline $5(17-000262)$ & $>6$ & $>6$ & 12.76 & $<2$ & $<2$ \\
\hline $12(17-000263)$ & $>6$ & $>6$ & 14.91 & $<2$ & $<2$ \\
\hline $24(17-000264)$ & $>6$ & $>6$ & 6.14 & $<1$ & $<1$ \\
\hline Acyclovir & 0.87 & $>150$ & $>150$ & $>172$ & 1 \\
\hline \multicolumn{6}{|l|}{ Human cytomegalovirus ${ }^{\mathrm{b}, \mathrm{c}}$} \\
\hline $1(17-000257)$ & 0.15 & $>6$ & 17.20 & 115 & $<3$ \\
\hline $6(17-000261)$ & $>1.20$ & $>1.20$ & 3.24 & $<3$ & $<3$ \\
\hline $8(17-000259)$ & 0.11 & $>6$ & 14.79 & 136 & $<2$ \\
\hline $14(17-000258)$ & $>1.20$ & $>1.20$ & 3.49 & $<3$ & $<3$ \\
\hline $15(17-000260)$ & 0.11 & $>6$ & 18.58 & 172 & $<3$ \\
\hline Ganciclovir & 0.24 & 1.08 & $>150$ & $>625$ & $>139$ \\
\hline $5(17-000262)$ & $>1.20$ & $>1.20$ & 4.08 & $<3$ & $<3$ \\
\hline $12(17-000263)$ & $>6$ & $>6$ & 15.32 & $<3$ & $<3$ \\
\hline $24(17-000264)$ & $>0.24$ & $>0.24$ & 1.18 & $<5$ & $<5$ \\
\hline Ganciclovir & 0.80 & $>150$ & $>150$ & $>187$ & 1 \\
\hline $2(18-000052)$ & $>1.20$ & $>1.20$ & 3.81 & $<3$ & $<3$ \\
\hline 7 (18-000053) & $>30$ & $>30$ & 86.48 & $<3$ & $<3$ \\
\hline $10(18-000051)$ & $>30$ & $>30$ & 89.45 & $<3$ & $<3$ \\
\hline $16(18-000049)$ & $>30$ & $>30$ & 80.86 & $<3$ & $<3$ \\
\hline Ganciclovir & 1.11 & $>150$ & $>150$ & $>135$ & 1 \\
\hline $1(17-000257)$ & $>6$ & $>6$ & 18.71 & $<3$ & $<3$ \\
\hline 8 (17-000259) & $>6$ & $>6$ & 16.14 & $<3$ & $<3$ \\
\hline $15(17-000260)$ & $>6$ & $>6$ & 17.56 & $<3$ & $<3$ \\
\hline Ganciclovir & $>150$ & $>150$ & $>150$ & 1 & 1 \\
\hline Cidofovir & 0.92 & $>30$ & 110.24 & 120 & $<4$ \\
\hline \multicolumn{6}{|l|}{ Human papillomavirus $11^{\mathrm{d}}$} \\
\hline $1(17-000257)$ & $>6$ & $>6$ & 11.89 & $<2$ & $<2$ \\
\hline 5 17-000262) & $>1.20$ & $>1.20$ & 5.16 & $<4$ & $<4$ \\
\hline $6(17-000261)$ & $>0.24$ & $>0.24$ & 0.78 & $<3$ & $<3$ \\
\hline $8(17-000259)$ & $>1.20$ & $>1.20$ & 3.32 & $<3$ & $<3$ \\
\hline $12(17-000263)$ & $>1.20$ & $>1.20$ & 4.79 & $<4$ & $<4$ \\
\hline $14(17-000258)$ & $>0.24$ & $>0.24$ & 0.78 & $<3$ & $<3$ \\
\hline $15(17-000260)$ & $>1.20$ & $>1.20$ & 1.34 & $<1$ & $<1$ \\
\hline $24(17-000264)$ & 1.07 & $>1.20$ & 2.83 & 3 & $>2$ \\
\hline $\begin{array}{l}\text { 9-[2-(Phosphonomethoxy)ethyl] } \\
\text { guanine }\end{array}$ & 0.68 & 100.62 & $>150$ & $>221$ & $>1$ \\
\hline
\end{tabular}

$\mathrm{EC}_{50}$ - compound concentration that reduced viral replication by $50 \%$; $\mathrm{EC}_{90}$-compound concentration that reduced viral replication by $90 \%$; $\mathrm{CC}_{50}$-compound concentration that reduced cell viability by $50 \%$; $\mathrm{SI}_{50}$ - selectivity index $\left(\mathrm{CC}_{50} / \mathrm{EC}_{50}\right)$

${ }^{a}$ Virus strain: E-377; cell line: HFF; vehicle: DMSO; drug conc. range: 0.048-150 $\mu \mathrm{M}$; control conc. range: 0.048-150 $\mu \mathrm{M}$; experiment number: 17-hsv1-033 for $\mathbf{1}, \mathbf{6}, \mathbf{8}, \mathbf{1 4}, \mathbf{1 5}$; 17-hsv1-034 for 5, 12, 24; control assay order: primary; control assay name: CellTiter-Glo (cytopathic effect/ toxicity)

${ }^{b}$ Virus strain: AD169; cell line: HFF; vehicle: DMSO; drug conc. range: 0.048-150 $\mu \mathrm{M}$; control conc. range: $0.048-150 \mu \mathrm{M}$; experiment number: 17-hcmv-028 for $\mathbf{1}, \mathbf{6}, \mathbf{8}, \mathbf{1 4}, \mathbf{1 5}$; 17-hcmv-029 for 5, 12, 24; 18-hcmv-009 for 2, 7, 10, 16; control assay order: primary; control assay name: CellTiter-Glo (cytopathic effect/toxicity)

${ }^{c}$ Virus strain: GDGr K17 (resistant isolate); cell line: HFF; vehicle: DMSO; drug conc. range: $0.01-30 \mu \mathrm{M}$; control conc. range: $0.048-150 \mu \mathrm{M}$; experiment number: 17-hcmvR-041 for 1, 8, 15; control assay order: primary; control assay name: CellTiter-Glo (cytopathic effect/toxicity)

${ }^{d}$ Virus strain: HE611260.1; cell line: C-33 A; vehicle: DMSO; drug conc. range: 0.048-150 $\mu \mathrm{M}$; control conc. range: $0.048-150 \mu \mathrm{M}$; experiment number: 17-hpv11-013; control assay name: Nano-Glo Luciferase (Nanoluc)/CellTiter-Glo (toxicity) 
of the NIAID for antiviral testing. The NIAID selected a panel of viruses [HCMV, HSV-1, and HPV 11 (HPV-11)] for in vitro screening of these compounds. The detailed information regarding antiviral screening and methods can be found at http://www.niaid-aacf.org/ and were described in the literature $[47,48]$.

The azepanobetulinic amide $\mathbf{6}$ and azepanoerythrodiol 14 have shown good viral inhibition towards HSV-1 $\left(\mathrm{EC}_{50}, \quad \mathrm{EC}_{90}>1.20 \mu \mathrm{M}\right)$ compared to standard drug Acyclovir $\left(\mathrm{EC}_{50}=0.83 \mu \mathrm{M} ; \mathrm{EC}_{90}>150 \mu \mathrm{M}\right)$. The azepanotriterpenoids 1, 8, 12, 15 and azepanobetulinic amides 5, 24 are active against $\mathrm{HSV}-1$ with $\mathrm{EC}_{50}>6 \mu \mathrm{M} ; \mathrm{EC}_{90}>$ $6 \mu \mathrm{M}$ (Table 3).

Just like HSV-1, compounds 2, 5, and 24, $\left(\mathrm{EC}_{50}>1.20\right.$; $>1.20$ and $>0.24 \mu \mathrm{M})$ turned out to be active towards HCMV for normal strain AD169 compared to Ganciclovir $\left(\mathrm{EC}_{50}=1.11 \mu \mathrm{M}(\mathbf{2}) ; \mathrm{EC}_{50}=0.80 \mu \mathrm{M}(\mathbf{5}, \mathbf{2 4})\right)$, and triterpenoids 6 and $\mathbf{1 4}$ showed weak activity with $\mathrm{EC}_{50}>1.20 \mu \mathrm{M}$ (ganciclovir $\mathrm{EC}_{50}=0.24 \mu \mathrm{M}$ ). Amide 7, azepanoallobetulin 10, abeo-lupane 12, and azepanoglycyrrhetol 16 were inactive against HCMV. The azepanobetulin 1, azepanouvaol 8, and azepano-glycyrrhetol 15 showed very high potency towards HCMV (EC ${ }_{50} 0.15$; $0.11 ; 0.11 \mu \mathrm{M}$, respectively), and relatively low toxicity $\left(\mathrm{CC}_{50} 17.20 ; 14.79 ; 18.58 \mu \mathrm{M}\right)$ with selectivity index $\left(\mathrm{SI}_{50} 115 ; 136 ; 172\right)$ compared to standard drug Ganciclovir $\left(\mathrm{EC}_{50} 0.24 \mu \mathrm{M} ; \mathrm{CC}_{50}>150.00 \mu \mathrm{M} ; \mathrm{SI}_{50}>625 \mu \mathrm{M}\right)$. The $\mathrm{EC}_{50}$ and $\mathrm{EC}_{90}$ values for compounds 1, 8, 15 against the resistant isolate GDGr K17 were higher than the values for the reference drug ganciclovir $\left(\mathrm{EC}_{50}>150 \mu \mathrm{M} ; \mathrm{EC}_{90}>\right.$ $150 \mu \mathrm{M})$, but at the same time lower $\mathrm{EC}_{50}$ value for cidofovir $\left(\mathrm{EC}_{50}=0.92 \mu \mathrm{M}\right)$.

The selectivity index $\left(\mathrm{SI}_{50}\right)$ for compounds $\mathbf{1 , 5}, \mathbf{6 , 8}, \mathbf{1 2}$, 14, 15, and 24 against HPV-11 ranged from 3 to $<4$. The amide $\mathbf{6}$ and azepanoerythrodiol $\mathbf{1 4}$ showed the best potency $\left(\mathrm{EC}_{50} ; \mathrm{EC}_{90}>0.24 \mu \mathrm{M}\right)$ compared to standard drug 9-[2-(phosphonomethoxy)ethyl]guanine $\quad\left(\mathrm{EC}_{50} \quad 0.68 \mu \mathrm{M}\right.$; $\left.\mathrm{EC}_{90} 100.62 \mu \mathrm{M}\right)$ (Table 3).

\section{Molecular modeling}

\section{Antibacterial activity}

In order to search for a possible mechanism of the antibacterial action of compound 4 against $S$. aureus, we performed molecular modeling of its possible interaction with a number of bacterial targets. A low estimated binding energy was obtained by docking compound 4 in S. aureus topoisomerase IV. Bacterial topoisomerase is involved in the processes of replication, damage repair, and topology changes of DNA molecule and, therefore, is an attractive target for the design of new inhibitors that will have antibacterial effects $[49,50]$. We used the $S$. aureus topoisomerase IV XRD model with PDB ID 4URN [51] (resolution $2.9 \AA$ ) for calculations.

The topoisomerase XRD model under consideration is co-crystallized with a naturally occurring antibiotic novobiocin. The authors of the model make a conclusion about the complex configuration of the binding site, which affects the resistance of topoisomerase to the action of antibiotics [51]. New antibiotics can occupy additional areas of the binding site and take on other conformations, overcoming resistance.

In this regard, according to docking the location of compound 4 in the binding site is interesting: it is able to penetrate into the deep pocket of the binding site with its aminocyclohexane group simulating the conformation of novobiocin. The azepane-triterpene backbone of this derivative occupies a mirror position relative to the novobiocin molecule (Fig. 2b), stabilizing its conformation due to the hydrogen bond of the protonated nitrogen atom of the azepane ring with the amino acid residue Val120 (Fig. 2a).

\section{Antiviral activity}

Considering the pronounced antiviral activity of compounds $\mathbf{1}, \mathbf{8}$, and 15 against cytomegalovirus, an attempt was made to
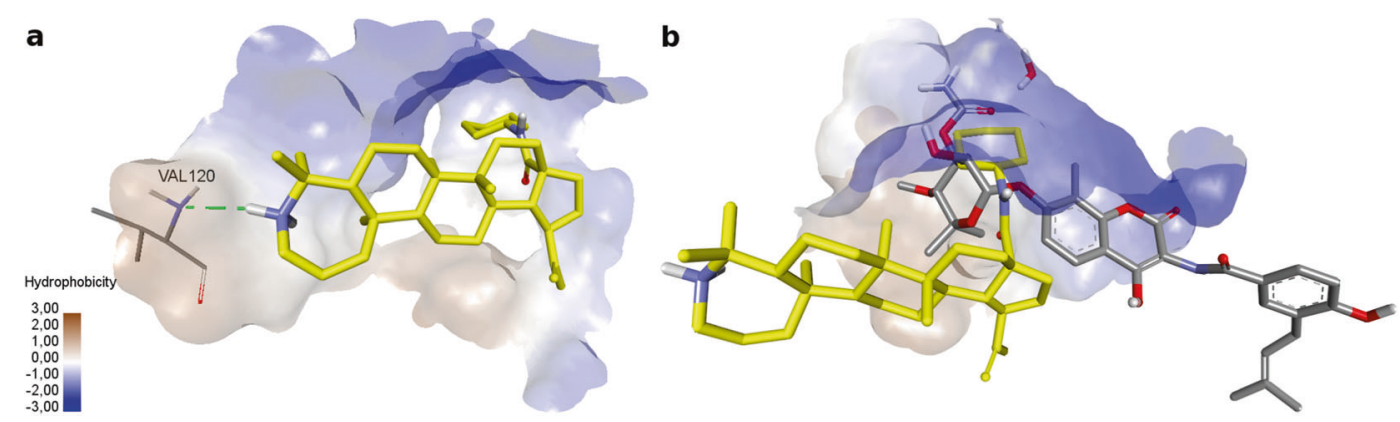

Fig. 2 a Docking of compound $4(-3.413 \mathrm{kcal} / \mathrm{mol})$ in $S$. aureus topoisomerase IV. Hydrogen bonds are shown by dashed green lines, hydrophobic interactions are omitted. b Superposition of the structures of compound $\mathbf{4}$ (yellow) and novobiocin (gray) at the topoisomerase binding site 
simulate a possible mechanism of the antiviral effect of these compounds. All human herpes viruses possess a structurally and functionally conserved serine protease [52]. This protease is critical for the formation of the viral nucleocapsid and is activated allosterically as a result of the dimerization process. Given one of the key roles of serine protease in the replication cycle of herpes viruses, it appears that inhibitors of this enzyme may be effective antiviral agents [53]. The development of covalent inhibitors capable of binding to the substrate-binding site has become a complex process due to its surface location, the absence of a deep cavity, and the high variability of its spatial organization [54, 55]. The allosteric nature of the activation of this enzyme is associated with two structurally different active sites of each monomer. Dimer formation leads to activation of the catalytic binding site. In this regard, blocking allosteric dimerization sites can lead to inhibition of viral protease activity [56]. To simulate a possible inhibition of allosteric dimerization of herpes virus protease by new azepanbetulin derivatives the XRD model of Kaposi's sarcoma-associated herpesvirus (KSHV) protease in complex with dimer disruptor with PDB ID 4P3H [56] (resolution 1, $45 \AA$ ) was chosen.

The active sites of dimerization of asymmetric monomers of the viral protease are deep hydrophobic cavities, in which the binding of possible dimer disruptors can be carried out mainly through hydrophobic interactions. Both sites are characterized by an open rotameric conformation of the Trp109 side chain, the pi system of which enters into stacking interactions with the pyrimidine ring of the dimer disruptor. In both sites, the disruptor molecule interacts with the amino acid residue Pro192 and water molecules. A specific feature of the binding of the disruptor in the active site of monomer $\mathrm{B}$ is the formation of a hydrogen bond with the Ser191 amino acid residue.

Modeling the interaction of new azepanbetulin derivatives with active sites of dimerization shows that the hydrophobicity of their triterpene scaffolds contributes to the formation of a large number of hydrophobic interactions in the depth of the binding cavity. All derivatives can interact with Trp109. Compounds 1 and 8 interact with Pro192 only in the active site of monomer B, while compound $\mathbf{1 5}$ interacts with it in both active sites of monomers. The polar groups of the new derivatives are apparently unable to form hydrogen bonds with water molecules and the Ser191 amino acid residue in the active site of monomer B. The proton of the hydroxyl group of compound $\mathbf{1}$ can enter into a hydrogen bond with the oxygen atom of Ala80 in the active site of monomer B. The presence of the five-membered ring $E$ in the structure of the triterpene core in combination with the hydrophobic center of propene, apparently, allows derivative $\mathbf{1}$ to penetrate deeper into the hydrophobic pocket of the active site of monomer $\mathrm{B}$, creating conformational opportunities for the interaction of the methanol substituent with Ala80 (Fig. 3). A hydrogen bond with an amino acid residue in the active site significantly reduces the estimated binding energy (Table 4).

Molecular modeling shows that hydrophobic structures of azepanbetulin derivatives are theoretically capable of entering the allosteric sites of herpes viral protease dimerization, blocking dimer assembly and inhibiting its function. According to the authors of the KSHV protease XRD model [56], dimer disruptors were the least effective against herpes viruses of the alpha family. This fact can confirm the absence of a pronounced antiviral effect of azepanbetulin derivatives against the herpes simplex virus.

\section{Experimental}

\section{General}

The spectra were recorded at the Center for the Collective Use "Chemistry" of the Ufa Institute of Chemistry of the UFRC RAS and RCCU "Agidel" of the UFRC RAS. ${ }^{1} \mathrm{H}$ and ${ }^{13} \mathrm{C}$ NMR spectra were recorded on a "Bruker AM500" (Bruker, Billerica, MA, USA, 500 and $125.5 \mathrm{MHz}$, respectively, $\delta, \mathrm{ppm}, \mathrm{Hz}$ ) in $\mathrm{CDCl}_{3}$, internal standard tetramethylsilane. Mass spectra were obtained on a liquid chromatograph-mass spectrometer LCMS-2010 EV (Shimadzu, Kyoto, Japan). Melting points were detected on a micro table "Rapido PHMK05" (Nagema, Dresden, Germany). Optical rotations were measured on a polarimeter "PerkinElmer 241 MC" (PerkinElmer, Waltham, MA, USA) in a tube length of $1 \mathrm{dm}$. Elemental analysis was performed on a Euro EA-3000 CHNS analyzer (Eurovector, Milan, Italy); the main standard is acetanilide. Thin-layer chromatography analyses were performed on Sorbfil plates (Sorbpolimer, Krasnodar, Russian Federation), using the solvent system chloroform-ethyl acetate, 40:1. Substances were detected by $10 \% \mathrm{H}_{2} \mathrm{SO}_{4}$ with subsequent heating to 100-120 ${ }^{\circ} \mathrm{C}$ for $2-3 \mathrm{~min}$. Compounds 1, 2 [57], 3, 17-20 [24], 4, 6, 9, 11, 12, 15, 16, 22, 23 [58], 5 [31], 7 [59], 8, 13 [22], 10, 21 [30], 14 [60], 25 [61], 28 [62], and 35 [63] were prepared by the literature methods. Oleanolic acid 27 was purchased from Xian RongSheng Biotechnology Co., Ltd.

\section{Chemistry}

\section{3-Deoxo-3a-homo-17-(imidazolino)-3a-aza-lup-20 (29)-en-carboxamide (24)}

To a solution of $1 \mathrm{mmol}(0.47 \mathrm{~g})$ compound 23 in dry $\mathrm{CH}_{2} \mathrm{Cl}_{2}(20 \mathrm{ml}) 1 \mathrm{mmol}(0.09 \mathrm{ml})(\mathrm{COCl})_{2}$ and three drops of $\mathrm{Et}_{3} \mathrm{~N}$ were added, the mixture was stirred for $3 \mathrm{~h}$ at $22{ }^{\circ} \mathrm{C}$, organic solvent was removed in vacuum. A solution of freshly prepared $1 \mathrm{mmol}$ A-azepanobetulinic acid chloride 
a

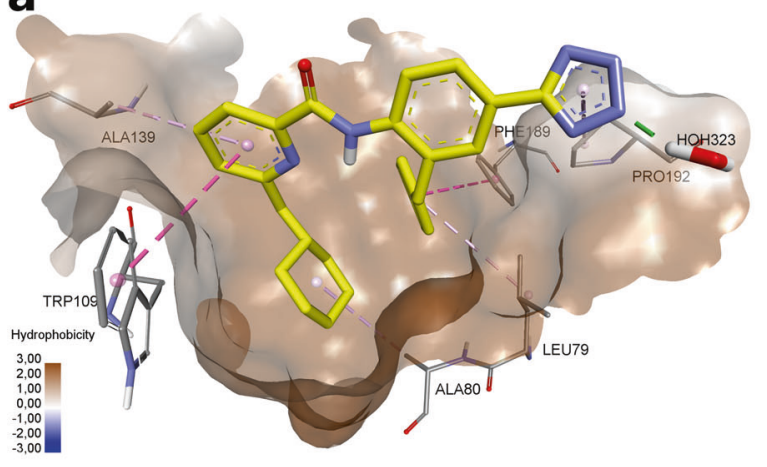

C

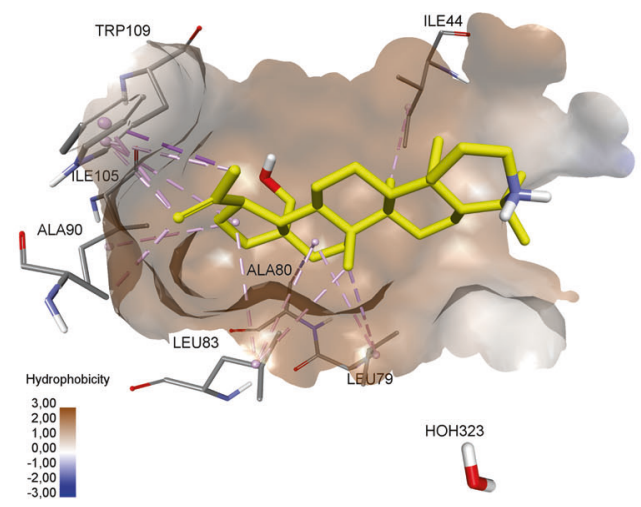

e

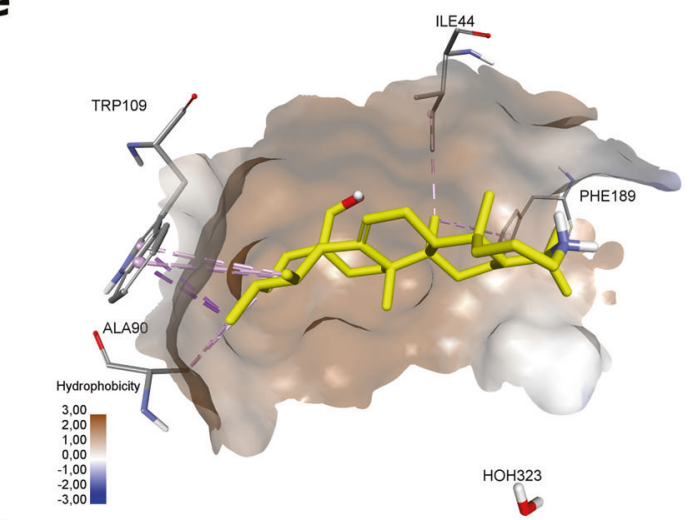

g

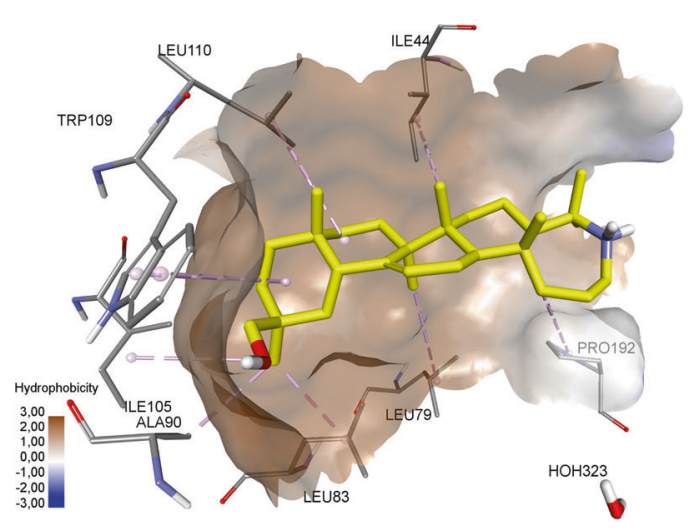

Fig. 3 Docking of compounds $\mathbf{1}, \mathbf{8}$ and $\mathbf{1 5}$ in KSHV protease asymmetric monomers binding sites (monomer A (a, c, e, g); monomer B (b, d, f, h). a $(-4.004 \mathrm{kcal} / \mathrm{mol})$, b $(-8.137 \mathrm{kcal} / \mathrm{mol})$-dimer disruptor; c, d compound $\mathbf{1}$; e, $\mathbf{f}$ compound $\mathbf{8} ; \mathbf{g}, \mathbf{h}$ compound $\mathbf{1 5}$.
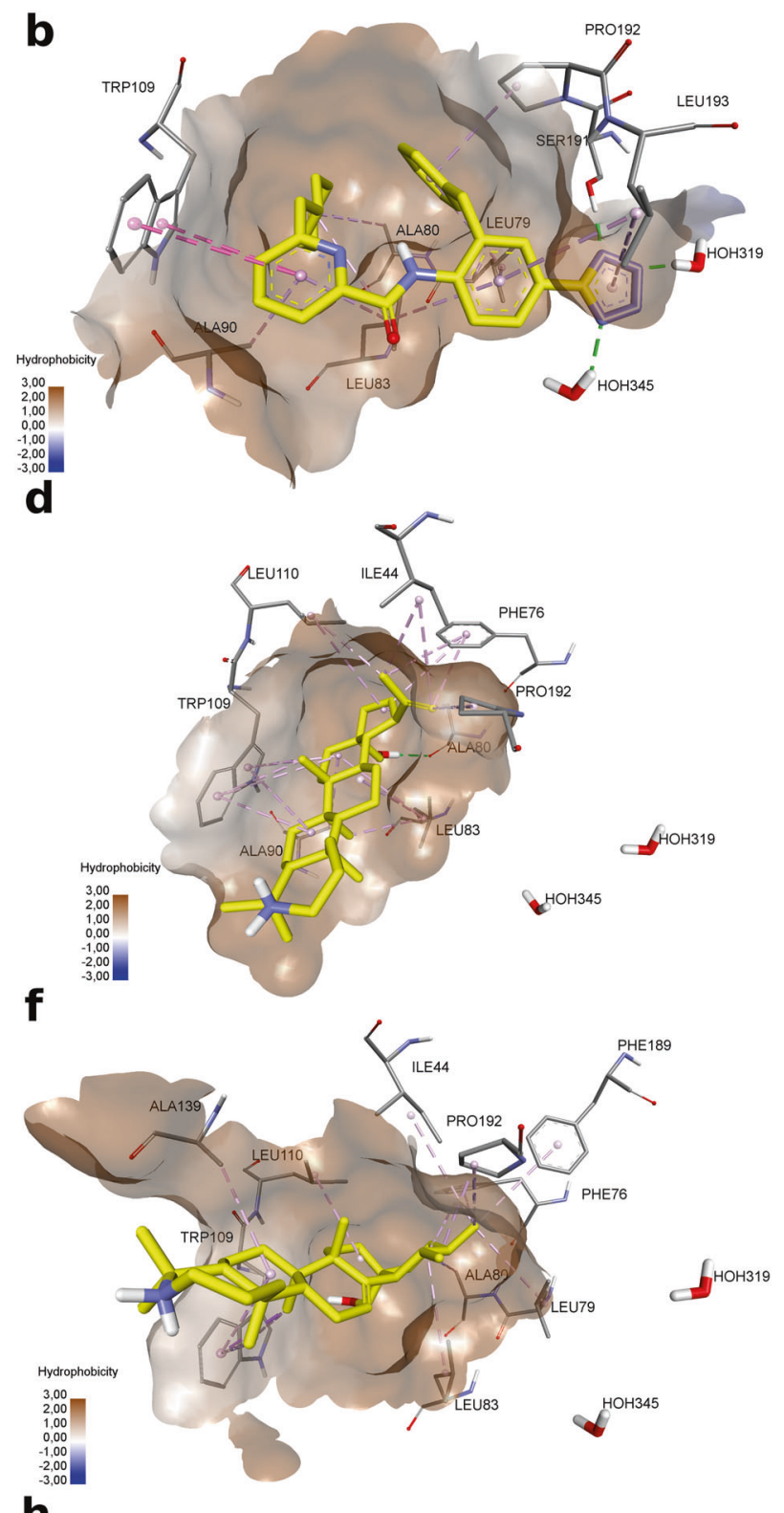

h

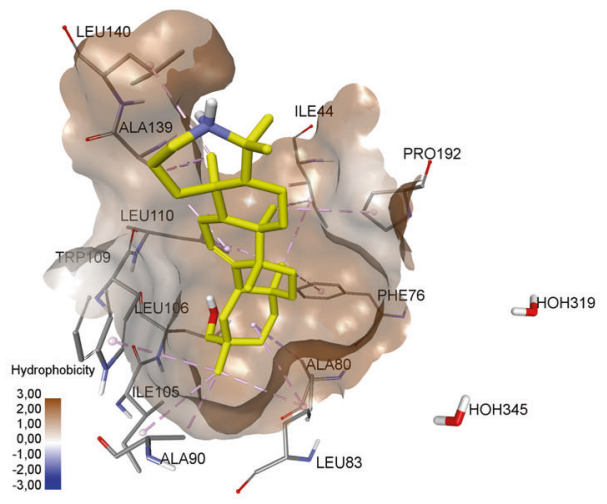

Noncovalent interactions of molecules are shown by dotted lines: green-hydrogen bonds, purple—stacking and pi-sigma interactions, pink-hydrophobic interactions 
Table 4 KSHV protease asymmetric monomers docking results

\begin{tabular}{lll}
\hline \multirow{2}{*}{ Ligand } & \multicolumn{2}{l}{ Binding energy $^{\mathrm{a}}, \mathrm{kcal} / \mathrm{mol}$} \\
\cline { 2 - 3 } & Monomer A & Monomer B \\
\hline Dimer disruptor (4P3H) & -4.004 & -8.137 \\
$\mathbf{1}$ & -5.350 & -7.244 \\
$\mathbf{8}$ & -4.491 & -5.185 \\
$\mathbf{1 5}$ & -4.372 & -5.641 \\
\hline
\end{tabular}

${ }^{a}$ Value is not genuine binding energy but estimated docking score

in dry $\mathrm{CH}_{2} \mathrm{Cl}_{2}(20 \mathrm{ml})$ was treated with $1.3 \mathrm{mmol}(0.09 \mathrm{~g})$ imidazole and a catalytic amount of DMAP with the following reflux during $3 \mathrm{~h}$. On completion of the reaction the mixture washed with $5 \% \mathrm{HCl}$ solution $(2 \times 100 \mathrm{ml})$ and $\mathrm{H}_{2} \mathrm{O}$ $(100 \mathrm{ml})$, dried over $\mathrm{CaCl}_{2}$, the solvent was removed under reduced pressure. Then a mixture of crude derivative $(1 \mathrm{mmol})$ and $2.2 \mathrm{mmol}(0.07 \mathrm{~g}) \mathrm{LiAlH}_{4}$ in dry THF $(20 \mathrm{ml})$ was refluxed for $1 \mathrm{~h}$, after cooling $\mathrm{H}_{2} \mathrm{O}(20 \mathrm{ml})$ and $10 \%$ $\mathrm{HCl}(10 \mathrm{ml})$ were added dropwise. The mixture was extracted with $\mathrm{CHCl}_{3}(3 \times 20 \mathrm{ml})$, the organic layer was washed with water and dried over $\mathrm{CaCl}_{2}$. The solvent was removed under reduced pressure, the residue was purified by column with $\mathrm{Al}_{2} \mathrm{O}_{3}$; the product was successively eluted chloroform, and a chloroform-ethanol mixture (50:1). Yield $(0.41 \mathrm{~g}, 82 \%)$, m.p. $261-263{ }^{\circ} \mathrm{C},[\alpha]_{D}{ }^{20}+18^{\circ}$ (c 0.003 , $\left.\mathrm{CHCl}_{3}\right) ; \delta_{H}\left(500.13 \mathrm{MHz}, \mathrm{CDCl}_{3}\right) 0.89$ (s, 3H, H25), 0.92 (s, 3H, H27), 1.14 (s, 3H, H26), 1.39 (s, 3H, H24), 1.48 (s, 3H, H23), 1.59 (s, 3H, H30), 1.17-1.40 (m, 12H), 1.502.30 (m, 14H), 2.89-3.37 (m, 2H, H19, NH), 4.61 (br.s, $1 \mathrm{H}$, H29a), 4.75 (br.s, 1H, H29b), 7.02 (s, 1H, CH), 7.28 (s, 1H, $\mathrm{CH}), 7.52(\mathrm{~s}, 1 \mathrm{H}, \mathrm{CH}) . \delta_{C}\left(125.76 \mathrm{MHz}, \mathrm{CDCl}_{3}\right) 14.8,16.1$, $19.3,21.3,21.8,22.7,26.9,27.9,28.0,29.0,30.6,33.0$, $34.0,36.9,37.6,39.4,40.9,41.3,42.4,42.9,45.0,48.5$, $51.3,54.7,57.9,59.9,63.2,109.7,117.5,128.9,137.2$, 150.2, 172.6. MS (APCI) $\mathrm{m} / z 504.79[\mathrm{M}-\mathrm{H}]^{-}$(calcd for $\mathrm{C}_{33} \mathrm{H}_{51} \mathrm{~N}_{3} \mathrm{O}$, 505.79). Anal. Calcd for $\mathrm{C}_{33} \mathrm{H}_{51} \mathrm{~N}_{3} \mathrm{O}: \mathrm{C}, 78.37$; H, 10.16; N, 8.31. Found: C, 78.39; H, 10.17; N, 8.27.

\section{3-Deoxy-3a-homo-17 $\beta$-(4- pyridinoylhydrazinocarbonyl)-3a-aza-urs-12(13)- en (26)}

To a solution of $1 \mathrm{mmol}(0.47 \mathrm{~g})$ compound 25 in dry $\mathrm{CH}_{2} \mathrm{Cl}_{2}(20 \mathrm{ml}) 1 \mathrm{mmol}(0.09 \mathrm{ml})(\mathrm{COCl})_{2}$ and three drops of $\mathrm{Et}_{3} \mathrm{~N}$ were added, the mixture was stirred for $3 \mathrm{~h}$ at $22^{\circ} \mathrm{C}$, organic solvent was removed in vacuum. A solution of 1 mmol $(0.49 \mathrm{~g})$ freshly prepared acid chloride in dry $\mathrm{CH}_{2} \mathrm{Cl}_{2}$ $(20 \mathrm{ml})$ was treated with the $1.3 \mathrm{mmol}(0.18 \mathrm{~g})$ 4pyridinoylhydrazide with following reflux during $3 \mathrm{~h}$. On completion of the reaction the mixture washed with $5 \% \mathrm{HCl}$ solution $(2 \times 100 \mathrm{ml})$ and $\mathrm{H}_{2} \mathrm{O}(100 \mathrm{ml})$, dried over $\mathrm{CaCl}_{2}$, the solvent was removed under reduced pressure. Then to a solution of $1 \mathrm{mmol}$ crude derivative in dry THF $(20 \mathrm{ml}) 2.2$ mmol $(0.07 \mathrm{~g}) \mathrm{LiAlH}_{4}$ was added, and the mixture was refluxed for $1 \mathrm{~h}$, then $\mathrm{H}_{2} \mathrm{O}(20 \mathrm{ml})$ and $10 \% \mathrm{HCl}(10 \mathrm{ml})$ were added dropwise. The mixture was extracted with $\mathrm{CHCl}_{3}(3 \times 20 \mathrm{ml})$, filtered, the organic layer was washed with water and dried over $\mathrm{CaCl}_{2}$. The solvent was removed under reduced pressure, the residue was purified by column with $\mathrm{Al}_{2} \mathrm{O}_{3}$; the product was successively eluted chloroform, and a chloroform-ethanol mixture (50:1, 25:1). Yield $0.41 \mathrm{~g} \quad(72 \%) ;$ m.p. $121-124^{\circ} \mathrm{C} ;[\alpha]_{D}{ }^{20}+36^{\circ}$ (c 0.05 , $\left.\mathrm{CHCl}_{3}\right) ; \delta_{H}\left(500.13 \mathrm{MHz}, \mathrm{CDCl}_{3}\right) 0.76,0.91,0.99,1.02$, $1.05,1.15,1.22\left(7 \mathrm{~s}, 21 \mathrm{H}, 7 \mathrm{CH}_{3}\right), 1.25-2.65(\mathrm{~m}, 25 \mathrm{H}, \mathrm{CH}$, $\mathrm{CH}_{2}$ ), 5.25 (br.s., $1 \mathrm{H}, \mathrm{H}-12$ ), 6.51 (br.s., $3 \mathrm{H}, 3 \mathrm{NH}$ ), 7.74 $(\mathrm{m}, 2 \mathrm{H}, \mathrm{CH}), 8.87(\mathrm{~m}, 2 \mathrm{H}, \mathrm{CH}) ; \delta_{C}\left(125.76 \mathrm{MHz}, \mathrm{CDCl}_{3}\right)$ $15.1,15.2,16.8,17.1,21.9,23.4,23.7,24.1,26.4,27.9$, $30.7,31.5,32.7,34.1,36.7,37.5,38.8,39.1,40.7,42.2$, 47.3, 47.9, 52.6, 55.2, 56.6, 63.2, 66.7, 120.9, 125.5, 128.3, 138.0, 138.5, 150.4, 150.9, 177.7 (NHCO), 182.5 (CONH); MS (APCI) $m / z 575.85[\mathrm{M}+\mathrm{H}]^{+}$(calcd for $\mathrm{C}_{36} \mathrm{H}_{54} \mathrm{~N}_{4} \mathrm{O}_{2}$, 574.85). Anal. Calcd for $\mathrm{C}_{36} \mathrm{H}_{54} \mathrm{~N}_{4} \mathrm{O}_{2}$ : C, 75.22; H, 9.47; N, 9.75. Found: C, 75.80; H, 9.40; N, 10.03 .

\section{Synthesis of compounds (29-31)}

To a solution of $1 \mathrm{mmol}(0.45 \mathrm{~g})$ compound 27 or $1 \mathrm{mmol}$ $(0.45 \mathrm{~g})$ compound 28 in dry $\mathrm{CH}_{2} \mathrm{Cl}_{2}(20 \mathrm{ml}) 1 \mathrm{mmol}(0.09 \mathrm{ml})$ $(\mathrm{COCl})_{2}$ and three drops of $\mathrm{Et}_{3} \mathrm{~N}$ were added, the mixture was stirred for $3 \mathrm{~h}$ at $22^{\circ} \mathrm{C}$, organic solvent was removed in vacuum. A solution of $1 \mathrm{mmol}$ freshly prepared corresponding acid chloride in dry $\mathrm{CH}_{2} \mathrm{Cl}_{2}(20 \mathrm{ml})$ was treated with the 1.3 mmol $(0.18 \mathrm{~g})$ 4-pyridinoylhydrazide (synthesis of compounds 29 and 30) or $1.3 \mathrm{mmol}(0.18 \mathrm{~g})$ 3-pyridinoylhydrazide (synthesis of compound 31) with following reflux during $3 \mathrm{~h}$. On completion of the reactions the solvent was evaporated in vacuum, the residues were washed with water, dried and then purified by column chromatography eluting by chloroform and chloroform-methanol (50:1).

\section{$3 \beta$-Hydroxy-17 $\beta$-(4-pyridinoylhydrazinocarbonyl)- olean-12(13)-en (29)}

Yield 0.46 g (76\%); m.p. $198-200{ }^{\circ} \mathrm{C} ;[\alpha]_{D}{ }^{20}+29^{\circ}(c 0.05$, $\left.\mathrm{CHCl}_{3}\right) ; \delta_{\mathrm{H}}\left(500.13 \mathrm{MHz}, \mathrm{CDCl}_{3}\right) 00.77,0.88,0.99,1.02$, $1.05,1.15,1.21\left(7 \mathrm{~s}, 21 \mathrm{H}, 7 \mathrm{CH}_{3}\right), 1.22-2.82(\mathrm{~m}, 23 \mathrm{H}, \mathrm{CH}$, $\mathrm{CH}_{2}$ ), 5.47 (br.s., $\left.1 \mathrm{H}, \mathrm{H}-12\right), 7.66\left(\mathrm{~d},{ }^{2} J=6.0 \mathrm{~Hz}, 2 \mathrm{H}, \mathrm{CH}\right)$, $8.64\left(\mathrm{~d},{ }^{2} J=5.8 \mathrm{~Hz}, 2 \mathrm{H}, \mathrm{CH}\right), 9.23$ (br.s., $2 \mathrm{H}, 2 \mathrm{NH}$ ); $\delta_{C}$ $\left(125.76 \mathrm{MHz}, \mathrm{CDCl}_{3}\right)$ 15.1, 15.2, 16.2, 19.4, 19.5, 21.5, 23.5, 23.6, 23.8, 25.7, 26.3, 27.2, 30.7, 31.8, 32.4, 32.9, 33.9, 34.1, 36.6, 39.1, 39.3, 41.3, 41.9, 46.1, 46.8, 47.4, 55.2, 121.2, $123.8,128.3,138.4,143.7,150.4,161.9$ (NHCO), 174.7 (CONH); MS (APCI) $\mathrm{m} / \mathrm{z}$ 576.85 $[\mathrm{M}+\mathrm{H}]^{+}$(calcd for $\mathrm{C}_{36} \mathrm{H}_{53} \mathrm{~N}_{3} \mathrm{O}_{3}$, 575.84). Anal. Calcd for $\mathrm{C}_{36} \mathrm{H}_{53} \mathrm{~N}_{3} \mathrm{O}_{3}$ : C, 75.09; H, 9.28; N, 7.30. Found: C, 74.89; H, 9.11; N, 7.53. 


\section{3-0xo-17 $\beta$-(4-pyridinoylhydrazinocarbonyl)-olean- 12(13)-en (30)}

Yield $0.47 \mathrm{~g}(78 \%)$; m.p. $166-168^{\circ} \mathrm{C} ;[\alpha]_{D}{ }^{20}+23^{\circ}(c$ 0.05, $\left.\mathrm{CHCl}_{3}\right) ; \delta_{H}\left(500.13 \mathrm{MHz}, \mathrm{CDCl}_{3}\right) \delta 0.76,0.89,0.99,1.01$, $1.05,1.15,1.21\left(7 \mathrm{~s}, 21 \mathrm{H}, 7 \mathrm{CH}_{3}\right), 1.22-2.82(\mathrm{~m}, 23 \mathrm{H}, \mathrm{CH}$, $\mathrm{CH}_{2}$ ), 5.47 (br.s., $1 \mathrm{H}, \mathrm{H}-12$ ), 7.67 (d, ${ }^{2} J=6.0 \mathrm{~Hz}, 2 \mathrm{H}, \mathrm{CH}$ ), $8.63\left(\mathrm{~d},{ }^{2} J=5.8 \mathrm{~Hz}, 2 \mathrm{H}, \mathrm{CH}\right), 9.21$ (br.s., $2 \mathrm{H}, 2 \mathrm{NH}$ ); $\delta_{C}$ $\left(125.76 \mathrm{MHz}, \mathrm{CDCl}_{3}\right) 15.1,15.3,16.2,19.4,19.5,21.4,23.5$, 23.6, 23.8, 25.7, 26.3, 27.2, 30.7, 31.8, 32.4, 32.9, 33.9, 34.1, $36.6,39.1,39.3,41.3,41.9,46.1,46.8,47.4,55.2,121.2$, 123.8, 128.3, 138.5, 143.7, 150.5, 161.9 (NHCO), 174.7 $(\mathrm{CONH}), 217.4(\mathrm{C}=\mathrm{O})$; MS (APCI) $\mathrm{m} / z 574.82[\mathrm{M}+\mathrm{H}]^{+}$ (calcd for $\mathrm{C}_{36} \mathrm{H}_{51} \mathrm{~N}_{3} \mathrm{O}_{3}, 573.82$ ). Anal. Calcd for $\mathrm{C}_{36} \mathrm{H}_{51} \mathrm{~N}_{3} \mathrm{O}_{3}$ : C, 75.35; H, 8.96; N, 7.32. Found: C, 75.38; H, 9.00; N, 7.30.

\section{3-0xo-17ß-(3-pyridinoylhydrazinocarbonyl)-olean- 12(13)-en (31)}

Yield $0.44 \mathrm{~g}(73 \%)$; m.p. $158-160^{\circ} \mathrm{C} ;[\alpha]_{D}{ }^{20}+34^{\circ}(c 0.05$, $\left.\mathrm{CHCl}_{3}\right) ; \delta_{H}\left(500.13 \mathrm{MHz}, \mathrm{CDCl}_{3}\right) 0.62,0.76,0.89,0.99$, $1.04,1.16,1.19\left(7 \mathrm{~s}, 21 \mathrm{H}, 7 \mathrm{CH}_{3}\right), 1.20-2.79(\mathrm{~m}, 23 \mathrm{H}, \mathrm{CH}$, $\mathrm{CH}_{2}$ ), 5.53 (br.s., $\left.1 \mathrm{H}, \mathrm{H}-12\right), 7.38(\mathrm{~m}, 1 \mathrm{H}, \mathrm{CH}), 8.18$ (m, $1 \mathrm{H}, \mathrm{CH}), 8.63$ (m, 1H, CH), 9.21 (m, 1H, CH), 10.71 (br.s., $2 \mathrm{H}, 2 \mathrm{NH}) ; \delta_{C}\left(125.76 \mathrm{MHz}, \mathrm{CDCl}_{3}\right) 15.1,16.2,19.5,21.5$, $23.5,23.7,23.8,25.7,26.3,27.3,30.7,31.8,32.1,32.9$, $33.9,34.1,36.6,39.2,39.3,41.5,42.0,46.1,46.2,46.8$, 47.5, 55.2, 123.3, 123.9, 127.4, 135.2, 143.8, 148.7, 152.6, $161.6(\mathrm{NHCO}), 174.0(\mathrm{CONH}), 217.5(\mathrm{C}=\mathrm{O})$; MS (APCI) $m / z$. $574.82[\mathrm{M}+\mathrm{H}]^{+}$(calcd for $\mathrm{C}_{36} \mathrm{H}_{51} \mathrm{~N}_{3} \mathrm{O}_{3}, 573.82$ ). Anal. Calcd for $\mathrm{C}_{36} \mathrm{H}_{51} \mathrm{~N}_{3} \mathrm{O}_{3}$ : C, 75.35; H, 8.96; N, 7.32. Found: C, 75.40; H, 9.05; N, 7.28.

\section{3-Deoxy-3a-homo-30-0-p-toluenesulfonyl-3a-aza- olean-12(13)-en (32)}

A mixture of $1 \mathrm{mmol}(0.43 \mathrm{~g})$ compound $15,1.5 \mathrm{mmol}$ $(0.29 \mathrm{~g}) p$-toluenesulfonyl chloride and a catalytic amount of DMAP in anhydrous pyridine $(30 \mathrm{ml})$ were stirred for 48 $\mathrm{h}$ at room temperature and poured into a $5 \% \mathrm{HCl}$ solution $(100 \mathrm{ml})$. The precipitate was filtered, washed with water, dried, and chromatographed on a column with $\mathrm{Al}_{2} \mathrm{O}_{3}$; the product was successively eluted with chloroform and a chloroform-ethanol mixture $(50: 1,40: 1)$. Yield $0.52 \mathrm{~g}$ (88\%); m.p. $140-146^{\circ} \mathrm{C} ;[\alpha]_{D}{ }^{20}+23^{\circ}\left(c 0.05, \mathrm{CHCl}_{3}\right) ; \delta_{H}$ $\left(500.13 \mathrm{MHz}, \mathrm{CDCl}_{3}\right) 0.69,0.72,1.05,1.13,1.21,1.41$, $1.49\left(7 \mathrm{~s}, 21 \mathrm{H}, 7 \mathrm{CH}_{3}\right), 0.92-2.12\left(\mathrm{~m}, 21 \mathrm{H}, \mathrm{CH}\right.$ and $\left.\mathrm{CH}_{2}\right)$, $2.42\left(\mathrm{~s}, 3 \mathrm{H}, \mathrm{CH}_{3}\right), 2.89\left(\mathrm{~m}, 2 \mathrm{H}, \mathrm{CH}_{2}\right), 3.21\left(\mathrm{~m}, 2 \mathrm{H}, \mathrm{CH}_{2}\right), 3$. 63 (br. s, $1 \mathrm{H}, \mathrm{NH}), 3.81-3.89\left(\mathrm{~m}, 1 \mathrm{H}, \mathrm{CH}_{2}\right), 3.70-3.81(\mathrm{~m}$, $\left.1 \mathrm{H}, \mathrm{CH}_{2}\right), 5.15$ (br.s., $\left.1 \mathrm{H}, \mathrm{H}-12\right), 7.35(\mathrm{~m}, 2 \mathrm{H}, \mathrm{CH}), 7.75$ $(\mathrm{m}, 2 \mathrm{H}, \mathrm{CH}) ; \delta_{C}\left(125.76 \mathrm{MHz}, \mathrm{CDCl}_{3}\right) 16.1,17.1,18.4$, $19.9,20.7,23.6,24.3,25.2,25.4,25.8,27.1,27.5,28.0$, $28.3,29.4,29.5,32.3,35.4,35.9,37.4,40.1,40.3,41.2$,
$42.5,44.1,46.6,50.8,54.5,73.9,123.1,127.9,127.9$, 129.8, 129.9, 132.9, 143.3, 144.6. MS (APCI) $\mathrm{m} / z .596 .93$ $[\mathrm{M}+\mathrm{H}]^{+}$(calcd for $\mathrm{C}_{37} \mathrm{H}_{57} \mathrm{NO}_{3} \mathrm{~S}, 595.93$ ). Anal. Calcd for $\mathrm{C}_{37} \mathrm{H}_{57} \mathrm{NO}_{3} \mathrm{~S}$ : C, 74.57; H, 9.64; N, 2.35; S, 5,38. Found: C, 73.71; H, 9.87; N, 2.32; S 5.42.

\section{3-Deoxy-3a-homo-3a-aza-lup-20(29)-en-28-al (33)}

To a mixture of $1 \mathrm{mmol}(0.43 \mathrm{~g})$ compound 1 in $50 \mathrm{ml} \mathrm{CH}_{2} \mathrm{Cl}_{2}$ $1 \mathrm{mmol}(0.02 \mathrm{~g})$ PCC was added. The mixture was stirred for $30 \mathrm{~min}$ at $25^{\circ} \mathrm{C}$, and then quenched by the addition of $9 \mathrm{ml}$ $\mathrm{MeOH}$, the resulting mixture was left for a while and then washed with dry ether and filtered. The solvent was removed and the residue was purified by column chromatography eluting by chloroform and chloroform-ethanol (50:1). Yield $0.32 \mathrm{~g}(73 \%)$; m.p. $266-268{ }^{\circ} \mathrm{C},[\alpha]_{D}{ }^{20}+55^{\circ}\left(\mathrm{c} 0.1, \mathrm{CHCl}_{3}\right)$; $\delta_{H}\left(500.13 \mathrm{MHz}, \mathrm{CDCl}_{3}\right) 0.80,1.11,1.20,1.25,1.30,1.70(6$ s, $18 \mathrm{H}, 6 \mathrm{CH}_{3}$ ), $1.80-2.50$ (m, 26H), 3.30 (br. s., $2 \mathrm{H}, \mathrm{H} 3$ ), 4.60 (s, 1H, H29b), 4.70 (s, 1H, H29a), 9.65 (br.s., $1 \mathrm{H}, \mathrm{CHO}$ ); $\delta_{C}$ $\left(125.76 \mathrm{MHz}, \mathrm{CDCl}_{3}\right)$ 13.9, 16.3, 16.3, 19.4, 19.9, 21.8, 22.2, $25.3,26.1,26.9,27.4,28.3,29.1,33.4,34.2,34.5,34.6,36.8$, 38.9, 39.5, 40.8, 41.1, 42.2, 42.9, 46.7, 54.4, 63.1, 110.2, 149.4, 206.4 (CHO). MS (APCI) $m / z, 440.73[\mathrm{M}+\mathrm{H}]^{+}$(calcd for $\mathrm{C}_{30} \mathrm{H}_{49} \mathrm{NO}$, 439.73). Anal. Calcd for $\mathrm{C}_{30} \mathrm{H}_{49} \mathrm{NO}$ : C, 81.94; H, 11.23; N, $3.19 \%$. Found: C, 81.95; H, 11.22; N, 3.19.

\section{3-Deoxy-3a-homo-3a-aza-28-(4- pyridinoylhydrazono)-lup-20(29)-en (34)}

A solution of $1 \mathrm{mmol}(0.44 \mathrm{~g})$ compound 33 and $1.3 \mathrm{mmol}$ $(0.18 \mathrm{~g})$ 4-pyridinoylhydrazide in $25 \mathrm{ml} \mathrm{MeOH}$ was stirred for $8 \mathrm{~h}$, and then poured into $100 \mathrm{ml} 5 \% \mathrm{HCl}$. The precipitate was filtered, washed with $\mathrm{H}_{2} \mathrm{O}$ and dried. The residue was purified by column chromatography eluting by chloroform and chloroform-ethanol (50:1). Yield $0.38 \mathrm{~g}$ (69\%), m.p. ${ }^{185}-187^{\circ} \mathrm{C},[\alpha]_{D} 20+35^{\circ}$ (c $0.003, \mathrm{CHCl}_{3}$ ); $\delta_{H}\left(500.13 \mathrm{MHz}, \mathrm{CDCl}_{3}\right) 0.70,0.85,0.98,1.01,1.10,1.90$ (6 s, $\left.18 \mathrm{H}, 6 \mathrm{CH}_{3}\right), 1.70-2.70$ (m, $\left.25 \mathrm{H}, \mathrm{CH}, \mathrm{CH}_{2}\right), 2.95$ (br.s., 1H, H3), 3.25 (br.s., 1H, H19), 4.55 (s, 1H, H29a), 4.65 (s, 1H, H29b), 7.55 (br.s., 1H, H28), 7.85 (br. s, 2H, CH), 8.78 (br. s, 2H, CH), $10.05(\mathrm{~s}, 2 \mathrm{H}, 2 \mathrm{NH}) ; \delta_{C}(125.76 \mathrm{MHz}$, $\mathrm{CDCl}_{3}$ ) 15.7, 16.3, 18.1, 19.3, 22.7, 23.3, 25.7, 26.2, 27.7, 28.6, 29.7, 30.7, 31.9, 33.5, 37.2, 38.6, 39.9, 40.8, 41.2, $42.7,46.9,47.5,48.0,49.0,54.2,56.5,62.3,109.4,121.1$, 123.4, 139.8, 149.3, 150.4, 150.9, 161.9 (NHCO), 166.0 $(\mathrm{CH}=\mathrm{N})$. MS (APCI) $\mathrm{m} / \mathrm{z} 559.76[\mathrm{M}+\mathrm{H}]^{+}$(calcd for $\mathrm{C}_{36} \mathrm{H}_{54} \mathrm{~N}_{4} \mathrm{O}$, 558.86). Anal. Calcd for $\mathrm{C}_{36} \mathrm{H}_{54} \mathrm{~N}_{4} \mathrm{O}$ : C, 77.37; H, 9.74; N, 10.03. Found: C, 77.39; H, 9.74; N, 10.04 .

\section{Synthesis of compounds $(36,37)$}

To a solution of $1 \mathrm{mmol}(0.44 \mathrm{~g})$ aldehyde 35 in dry $\mathrm{MeOH}$ $(60 \mathrm{ml}) 2.0 \mathrm{mmol}(0.28 \mathrm{~g})$ 3-pyridinoylhydrazide was added, 
the mixture was stirred $6 \mathrm{~h}$, then poured into $\mathrm{H}_{2} \mathrm{O}(100 \mathrm{ml})$. The precipitate was filtered, washed with water and dried. The crude product was purified by column chromatography eluting by chloroform and chloroform-ethanol (50:1).

\section{3-0xo-28-(4-pyridinoylhydrazono)-lup-20(29)-en (36)}

Yield $0.37 \mathrm{~g}(65 \%)$; m.p. $164-167^{\circ} \mathrm{C},[\alpha]_{D}{ }^{20}+55^{\circ}(c 0.1$, $\left.\mathrm{CHCl}_{3}\right) ; \delta_{H}\left(500.13 \mathrm{MHz}, \mathrm{CDCl}_{3}\right) 0.79,0.99,1.00,1.17$, $1.25,1.65\left(6 \mathrm{~s}, 18 \mathrm{H}, 6 \mathrm{CH}_{3}\right), 1.10-2.80\left(\mathrm{~m}, 25 \mathrm{H}, \mathrm{CH}, \mathrm{CH}_{2}\right)$, 4.50 (s, 1H, H29a), 4.65 (s, 1H, H29b), 7.25 (br. s, 1H, $\mathrm{H} 28), 7.99(\mathrm{~m}, 1 \mathrm{H}, \mathrm{CH}), 8.25(\mathrm{~m}, 1 \mathrm{H}, \mathrm{CH}), 8.67(\mathrm{~m}, 1 \mathrm{H}$, $\mathrm{CH}), 9.15(\mathrm{~m}, 1 \mathrm{H}, \mathrm{CH}), 10.60$ (br.s, $1 \mathrm{H}, \mathrm{NH}) ; \delta_{C}(125.76$ $\left.\mathrm{MHz}, \mathrm{CDCl}_{3}\right)$ 14.5, 15.9, 19.0, 19.6, 21.0, 25.1, 26.6, 27.9, $29.7,32.3,33.4,34.1,36.8,38.3,38.8,39.5,40.7,42.8$, $47.3,47.9,48.3,49.1,49.3,49.6,51.1,54.7,110.2,122.6$, $129.5,137.5,149.6,153.5,158.6,161.9(\mathrm{CH}=\mathrm{N}), 168.3$ (NHCO), $218.5(\mathrm{C}=\mathrm{O})$. MS (APCI) $\mathrm{m} / z 558.82[\mathrm{M}+\mathrm{H}]^{+}$ (calcd for $\mathrm{C}_{36} \mathrm{H}_{51} \mathrm{~N}_{3} \mathrm{O}_{2}$, 557.82). Anal. Calcd for $\mathrm{C}_{36} \mathrm{H}_{51} \mathrm{~N}_{3} \mathrm{O}_{2}$ : C, 77.51; H, 9.22; N, 7.53. Found: C, 77.55; $\mathrm{H}, 9.25 ; \mathrm{N}, 7.58$.

\section{3,28-Di-(4-pyridinoylhydrazono)-lup-20(29)-en (37)}

Yield $0.05 \mathrm{~g}(7 \%)$; m.p. $168-170^{\circ} \mathrm{C},[\alpha]_{D}{ }^{20}+45^{\circ}$ (c 0.1 , $\left.\mathrm{CHCl}_{3}\right) ; \delta_{H}\left(500.13 \mathrm{MHz}, \mathrm{CDCl}_{3}\right) 0.79,0.98,1.00,1.18$, $1.14,1.66\left(6 \mathrm{~s}, 18 \mathrm{H}, 6 \mathrm{CH}_{3}\right), 1.12-2.80\left(\mathrm{~m}, 25 \mathrm{H}, \mathrm{CH}, \mathrm{CH}_{2}\right)$, 4.50 (s, 1H, H29a), 4.65 (s, 1H, H29b), 7.25 (br. s, 1H, H28), 7.99 (m, 2H, CH), 8.35 (m, 2H, CH), 8.67 (m, 2H, CH), 9.20 (m, 2H, CH), 10.99 (br.s, 2H, 2NH); $\delta_{C}(125.76 \mathrm{MHz}$, $\left.\mathrm{CDCl}_{3}\right)$ 14.5, 15.7, 19.0, 19.5, 21.2, 25.1, 26.6, 27.9, 29.7, $32.4,33.5,34.1,36.7,36.9,38.3,38.8,39.5,40.7,42.8,47.3$, $47.9,48.3,49.1,49.3,49.6,50.8,54.9,110.2,122.6,123.6$, $128.3,129.4,136.3,137.5,148.1,149.6,150.7,151.8,153.4$, $158.6(\mathrm{CH}=\mathrm{N}), 161.9(\mathrm{C}=\mathrm{N}), 168.2(\mathrm{NHCO}) . \mathrm{MS}(\mathrm{APCI})$ $m / z 677.95[\mathrm{M}+\mathrm{H}]^{+}$(calcd for $\mathrm{C}_{42} \mathrm{H}_{56} \mathrm{~N}_{6} \mathrm{O}_{2}, 676.95$ ). Anal. Calcd for $\mathrm{C}_{42} \mathrm{H}_{56} \mathrm{~N}_{6} \mathrm{O}_{2}$ : C, 74.52; H, 8.34; N, 12.41. Found: C, 74.60; H, 8.40; N, 12.40 .

\section{Biology}

All biology experimental procedures and molecular modeling methods are described in the Supplementary materials.

\section{Conclusions}

Thus, we have synthesized a series of semisynthetic triterpenoids bearing A-azepano-, A-seco-3-amino-, and hydrazido/hydrazono fragments and their antimicrobial activity against key ESKAPE pathogens and DNA viruses was evaluated. Azepanobetulinic acid cyclohexyl amide $\mathbf{4}$ displayed good antibacterial activity that exceeds the effect of the clinically used antibiotic vancomycin, low cytotoxicity to HEK-293 and selectivity index SI 133 even at a maximum tested concentration of $>10 \mu \mathrm{M}$ and hence showed greatest potential for further investigations as noncytotoxic anti-MRSA agent. Azepanobetulin 1, azepanouvaol 8, and azepano-glycyrrhetol $\mathbf{1 5}$ showed high potency towards $\mathrm{HCMV}\left(\mathrm{EC}_{50} 0.15 ; 0.11 ; 0.11 \mu \mathrm{M}\right)$ with selectivity indexes $\mathrm{SI}_{50} 115 ; 136 ; 172$, respectively. The docking studies suggest the possible interactions of the leading compounds with the molecular targets.

Acknowledgements This work was supported by Federal program AAAA-A20-120012090023-8. The study of antiviral activity was funded in whole or in part with Federal funds from the National Institutes of Allergy and Infectious Diseases, National Institutes of Health, Department of Health and Human Services, under contract HHSN272201100016I (MNP). The antimicrobial screening was performed by CO-ADD (The Community for Antimicrobial Drug Discovery), funded by the Wellcome Trust (UK) and The University of Queensland (Australia).

\section{Compliance with ethical standards}

Conflict of interest The authors declare no competing interests.

Publisher's note Springer Nature remains neutral with regard to jurisdictional claims in published maps and institutional affiliations.

\section{References}

1. Owens RC Jr. Antimicrobial stewardship: concepts and strategies in the 21st century. Diagn Microbiol Infect Dis. 2008;61:110-28.

2. WHO. Antimicrobial resistance: global report on surveillance. Geneva: World Health Organization; 2014. http://apps.who.int/ iris/bitstream/10665/112642/1/9789241564748_eng.pdf?ua=1.

3. Cappiello F, Loredo MR, Del Plato C, Cammarone S, Casciaro B, Quaglio D, et al. The revaluation of plant-derived terpenes to fight antibiotic-resistant infections. Antibiotics. 2020;9:325.

4. Anand U, Jacobo-Herrera N, Altemimi A, Lakhssassi N. A comprehensive review on medicinal plants as antimicrobial therapeutics: Potential avenues of biocompatible drug discovery. Metabolites. 2019;9:258.

5. Wozniak L, Skapska S, Marszalek K. Ursolic acid-A pentacyclic triterpenoid with a wide spectrum of pharmacological activities. Molecules. 2015;20:20614-41.

6. Calixto JB. The role of natural products in modern drug discovery. Acad Bras Cienc. 2019;91:e20190105.

7. Bucar F, Wube A, Schmid M. Natural product isolation-how to get from biological material to pure compounds. Nat Prod Rep. 2013;30:525-45.

8. Tolstikov GA, Flekhter OB, Shul'ts EE, Baltina LA, Tolstikov AG. Betulin and its derivatives. Chemistry and biological activity. Khim Interes Ustoich Razvit (Chem Sustain Dev). 2005;13:1-30.

9. Tolstikova TG, Sorokina IV, Tolstikov GA, Tolstikov AG, Flechter OB. Biological activity and pharmacological prospects of Lupane Terpenoids: I. Natural Lupane derivatives. Russ J Bioorg Chem. 2006;32:37-49.

10. Krasutsky PA. Birch bark research and development. Nat Prod Rep. 2006;23:919-42.

11. Csuk R. Betulinic acid and its derivatives: a patent review (20082013). Expert Opin Ther Pat. 2014;24:913-23. 
12. Sousa JLC, Freire CSR, Silvestre AJD, Silva AMS. Recent developments in the functionalization of betulinic acid and its natural analogues: a route to new bioactive compounds. Molecules. 2019;24:355.

13. Bildziukevich U, Özdemir Z, Wimmer Z. Recent achievements in medicinal and supramolecular chemistry of betulinic acid and its derivatives. Molecules. 2019;24:3546.

14. Chung PY, Navaratnam P, Chung LY. Synergistic antimicrobial activity between pentacyclic triterpenoids and antibiotics against Staphylococcus aureus strains. Ann Clin Microbiol Antimicrob. 2011;10:25.

15. Gibbons S. Anti-staphylococcal plant natural products. Nat Prod Rep. 2004;21:263-77.

16. Wang CM, Chen HT, Wu ZY, Jhan YL, Shyu CL, Chou CH. Antibacterial and synergistic activity of pentacyclic triterpenoids isolated from Alstonia scholaris. Molecules. 2016;21:139

17. Fujioka T, Kashiwada Y, Kilkuskie RE, Cosentino LM, Ballas LM, Jiang JB, et al. Anti-AIDS agents, 11. Betulinic acid and platanic acid as anti-HIV principles from Syzigium claviflorum, and the anti-HIV activity of structurally related triterpenoids. J Nat Prod. 1994;57:243-47.

18. Mayaux JF, Bousseau A, Pauwels R, Huet T, Henin Y, Dereu N, et al. Triterpene derivatives that block entry of human immunodeficiency virus type 1 into cells. Proc Natl Acad Sci USA. 1994;91:3564-8.

19. Cinatl J, Morgenstern B, Bauer G, Chandra P, Rabenau H, Doerr HW. Glycyrrhizin, an active component of liquorice roots, and replication of SARS-associated coronavirus. Lancet. 2003;361:2045-46.

20. Yu F, Wang Q, Zhang Z, Peng Y, Qiu Y, Shi Y, et al. Development of oleanane-type triterpenes as a new class of HCV entry inhibitors. J Med Chem. 2013;56:4300-19.

21. Si LL, Meng K, Tian ZY, Sun JQ, Li HQ, Zhang ZW, et al. Triterpenoids manipulate a broad range of virus-host fusion via wrapping the HR2 domain prevalent in viral envelopes. Sci Adv. 2018;4:eaau8408

22. Medvedeva NI, Kazakova OB, Lopatina TV, Smirnova IE, Giniyatullina GV, Baikova IP, et al. Synthesis and antimycobacterial activity of triterpenic A-ring azepanes. Eur J Med Chem. 2018;143:464-72.

23. Kazakova OB, Lopatina TV, Baikova IP, Zileeva ZR, Vakhitova YV, Suponitsky KYU. Synthesis, evaluation of cytotoxicity, and antimicrobial activity of A-azepano- and A-seco-3-amino-C28aminolupanes. Med Chem Res. 2020;29:1507-19.

24. Kazakova OB, Medvedeva NI, Smirnova IE, Lopatina TV, Veselovsky AV. The introduction of hydrazone, hydrazide, or azepane moieties to the triterpenoid core enhances an activity against M. tuberculosis. Med Chem. 2020;16:1-12.

25. Kazakova OB, Medvedeva NI, Samoilova IA, Baikova IP, Tolstikov GA, Kataev VE, et al. Conjugates of several lupane, oleanane, and ursane triterpenoids with the antituberculosis drug isoniazid and pyridinecarboxaldehydes. Chem Nat Compd. 2011; 47:752-58.

26. Brown ED, Wright GD. Antibacterial drug discovery in the resistance era. Nature. 2016;529:336-43.

27. WHO. Antibiotic resistance. 2017. http://www.who.int/media centre/factsheets/antibiotic-resistance/en/.

28. Osbourn AE, Lanzotti V. Plant-derived natural products. Dordrecht, The Netherlands: Springer; 2009. p. 361-84. https://doi. org/10.1007/978-0-387-85498-4.

29. Subramani R, Narayanasamy M, Feussner KD. Plant-derived antimicrobials to fight against multi-drugresistant human pathogens. Biotech. 2017;7:172.

30. Kazakova OB, Brunel JM, Khusnutdinova EF, Negrel S, Giniyatullina GV, Lopatina TV, et al. A-ring modified triterpenoids and their spermidine-aldimines with strong antibacterial activity. Molbank. 2019;M1078. https://doi.org/10.3390/M1078

31. Kazakova O, Lopatina T, Giniyatullina G, Mioc M, Soica C. Antimycobacterial activity of azepanobetulin and its derivative: In vitro, in vivo, ADMET and docking studies. Bioorg Chem. 2020;104:104209.

32. Xiao S, Tian Z, Wang Y, Si L, Zhang L, Zhou D. Recent progress in the antiviral activity and mechanism study of pentacyclic triterpenoids and their derivatives. Med Res Rev. 2018;38:951-76.

33. Lee KH. Discovery and development of natural product-derived chemotherapeutic agents based on a medicinal chemistry Approach. J Nat Prod. 2010;73:500-16.

34. Kashiwada $Y$, Nagao $T$, Hashimoto A, Ikeshiro $Y$, Okabe $H$, Cosentino LM, et al. Anti-AIDS agents 38. Anti-HIV activity of 3-O-acyl ursolic acid derivatives. J Nat Prod. 2000;63:1619-22.

35. Deng SL, Baglin I, Nour M, Flekhter O, Vita C, Cavé C. Synthesis of ursolic phosphonate derivatives as potential Anti-HIV Agents. Phosph Sulfur Silicon Relat Elem. 2007;182:951-67.

36. Gong Y, Raj KM, Luscombe CA, Gadawski I, Tam T, Chu J, et al. The synergistic effects of betulin with acyclovir against herpes simplex viruses. Antivir Res. 2004;64:127-130.

37. Baltina LA, Flekhter OB, Nigmatullina LR, Boreko EI, Pavlova NI, Nikolaeva SN, et al. Lupane triterpenes and derivatives with antiviral activity. Bioorg Med Chem Lett. 2003;13:3549-52.

38. Pavlova NI, Savinova OV, Nikolaeva SN, Boreko EI, Flekhter OB. Antiviral activity of betulin, betulinic and betulonic acids against some enveloped and non-enveloped viruses. Fitoterapia. 2003;74:489-92.

39. Savinova OV, Pavlova NI, Boreko EI. New betulin derivatives in combination with rimantadine for inhibition of influenza virus reproduction. Antibiot Khimioter. 2009;54:16-20.

40. Pohjala L, Alakurtti S, Ahola T, Yli-Kauhaluoma J, Tammela P. Betulin-derived compounds as inhibitors of alphavirus replication. J Nat Prod. 2009;72:1917-26.

41. Karagöza AÇ, Leidenberger M, Hahn F, Hampel F, Friedrich O, Marschall M, et al. Synthesis of new betulinic acid/betulin-derived dimers and hybrids with potent antimalarial and antiviral activities. Bioorg Med Chem. 2019;27:110-15.

42. Ngoc TD, Moons N, Kim Y, Borggraeve W, Mashentseva A, Andrei G, et al. Synthesis of triterpenoid triazine derivatives from allobetulone and betulonic acid with biological activities. Bioorg Med Chem. 2014;13:3292-300.

43. Shah KV, Howley PM. Papillomaviruses. In: Field BN, Knipe DM, Howley PM, editors. Fields virology. Philadelphia, PA: Lippincott-Raven; 1996. p. 2077-109.

44. Kazakova OB, Giniyatullina GV, Yamansarov EY, Tolstikov GA. Betulin and ursolic acid synthetic derivatives as inhibitors of Papilloma virus. Bioorg Med Chem Lett. 2010;20:4088-90.

45. Kazakova OB, Medvedeva NI, Baikova IP, Tolstikov GA, Lopatina TV, Yunusov MS, et al. Synthesis of triterpenoid acylates: Effective reproduction inhibitors of influenza A (H1N1) and papilloma viruses. Russ J Bioorg Chem. 2010;36:771-78.

46. Khusnutdinova EF, Kazakova OB, Lobov AN, Kukovinets OS, Suponitsky Kyu, Meyers CB. et al. Synthesis of A-ring quinolones, nine-membered oxolactams and spiroindoles by oxidative transformations of 2,3-indolotriterpenoids. Org Biomol Chem. 2019;17:585-97.

47. Prichard MN, Williams JD, Komazin-Meredith G, Khan AR, Price NB, Jefferson GM, et al. Synthesis and antiviral activities of methylenecyclopropane analogs with 6-alkoxy and 6alkylthio substitutions that exhibit broad-spectrum antiviral activity against human herpesviruses. Antimicrob Agents Chemother. 2013;57:3518-27.

48. Smee DF, Huffman JH, Morrison AC, Barnard DL, Sidwell RW. Cyclopentane neuraminidase inhibitors with potent in vitro 
anti-influenza virus activities. Antimicrob Agents Chemother. 2001;45:743-48.

49. Lahiri SD, Kutschke A, McCormack K, Alm RA. Insights into the mechanism of inhibition of novel bacteria topoisomerase inhibitors from characterization of resistant mutants of Staphylococcus aureus. Antimicrob Agents Chemother 2015; 59:5278-87.

50. Badshah SL, Ullah A. New developments in non-quinolone-based antibiotics for the inhibiton of bacterial gyrase and topoisomerase IV. Eur J Med Chem. 2018;152:393-400.

51. Lu J, Patel S, Sharma N, Stephen M, Soisson SM, Kishii R, et al. Structures of kibdelomycin bound to Staphylococcus aureus GyrB and ParE showed a novel U-shaped binding mode. ACS Chem Biol. 2014;9:2023-31.

52. Tong L. Viral proteases. Chem Rev. 2002;102:4609-26.

53. Gao M, Matusick-Kumar L, Hurlburt W, DiTusa SF, Newcomb WW, Brown JC, et al. The protease of herpes simplex virus type 1 is essential for functional capsid formation and viral growth. $\mathrm{J}$ Virol. 1994;68:3702-12.

54. Waxman L, Darke PL. The herpesvirus proteases as targets for antiviral chemotherapy. Antivir Chem Chemother. 2000;11:1-22.

55. Lazic A, Goetz DH, Nomura AM, Marnett AB, Craik CS. Substrate modulation of enzyme activity in the herpesvirus protease family. J Mol Biol. 2007;373:913-23.

56. Gable JE, Lee GM, Jaishankar P, Hearn BR, Waddling CA, Renslo AR, et al. Broad-spectrum allosteric inhibition of herpesvirus proteases. Biochemistry. 2014;53:4648-60.
57. Lopatina TV, Medvedeva NI, Baikova IP, Iskhakov AS, Kazakova OB. Synthesis and cytotoxicity of $O$ - and $N$-acyl derivatives of azepanobetulin. Russ J Bioorg Chem. 2019; 45:292-301.

58. Kazakova O, Smirnova I, Lopatina T, Giniyatullina G, Petrova A, Khusnutdinova E, et al. Synthesis and cholinesterase inhibiting potential of A-ring azepano- and 3-amino-3,4-seco-triterpenoids. Bioorg Chem. 2020;101:104001.

59. Giniyatullina GV, et al. Synthesis and cytotoxicity of $\mathrm{N}$ methylpiperazinylamide azepanobetulinic acid. Nat Prod Comm. 2019;14:1-5.

60. Kazakova OB, Rubanik LV, Smirnova IE, Savinova OV, Petrova AV, Poleschuk NN, et al. Synthesis and in vitro activity of oleanane type derivatives against Chlamydia trachomatis. Org Commun. 2019;12:169-75.

61. Gnoatto SCB, Dassonville-Klimpt A, Da Nascimento S, Galéra P, Boumediene K, Gosmann G, et al. Evaluation of ursolic acid isolated from Ilex paraquariensis and derivatives on inhibition. Eur J Med Chem. 2008;43:1865-77.

62. Ma CM, Nakamura N, Hattori M. Chemical modification of oleanene type triterpenes and their inhibitory activity against HIV1 protease dimerization. Chem Pharm Bull. 2000;48:1681-88.

63. Flekhter OB, Ashavina OY, Boreko EI, Karachurina LT, Pavlova NI, Kabal'nova NN, et al. Synthesis of 3-O-acetylbetulinic and betulonic aldehydes according to svern and the pharmacological activity of related oximes. Pharm Chem J. 2002;36:303. https://doi. org/10.1023/A:1020824506140 